تطوير أداء مدير الروضة فى ضوء المعايير القومية لرياض الأطفال

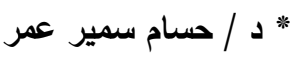

\title{
همص البمث
}

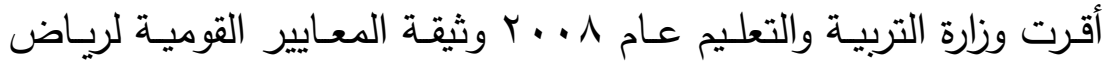
الأطفال ، والتي تتكون من ست مجالات تمثل في مجموعها عناصر منظومـة

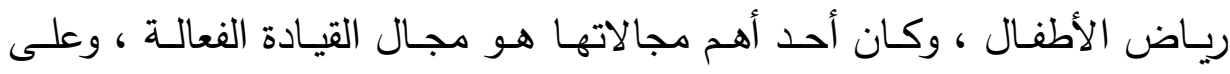

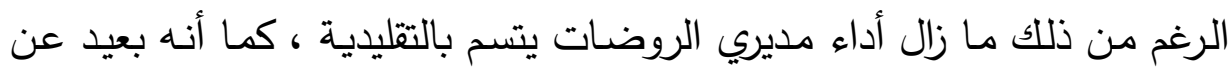
تطبيقات معايير ومؤشرات مجال القيادة الفعالة بوثيقة المعايير القومية ، من هذا المنطلق ، يمكن تحديد مشكلة الدراسة الحالية من خلال التساؤلات التالية : () ما الأدوار والمسئوليات والمهارات الواجب توافرها في مدير الروضة للمساهمة

$$
\text { في نجاح العملية التربوية برياض الأطفال ؟ }
$$

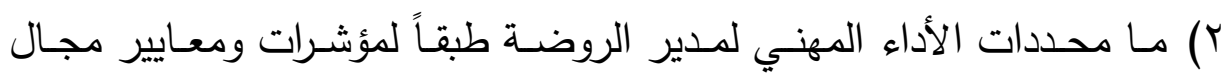

$$
\text { القيادة الفعالة ؟ }
$$

r) ما مقترحات تطوير أداء مدير الروضة في ضوء مجال القيادة الفعالة ؟

\section{هنههج الدراسة : مستر}

اسـتخدم الباحث " المـنهج الوصـفى التحليلي " وهـو المـنهج الذني يقوم بوصف ما هو كائن وتفسيره وذللك باعتباره المنهج البحثي الملائم لطبيعة مشكلة البحث

\section{مقترحات الدراسة : مقاه}

عرضت الدراسة بعض المقترحات للمعارف والمهارات اللازمة لوضع هذه

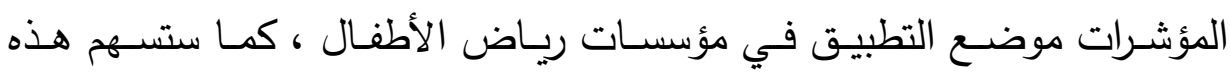
المقترحات في تحديد إجراءات التقييم الذاتي لمديري الروضـات ، والتقييم الذي

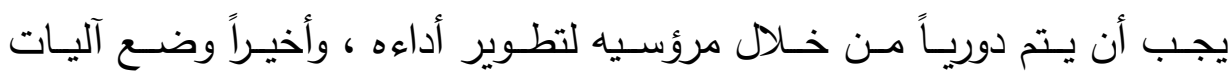
المحاسبية للجهات المعنية بوزارة التربية والتعليم • * مدرس تربية الطفل ـ قسم العلوم التربوية ـ كلية رياض الأطفال - جامعة دمنهور 


\section{تطوير أداء هدير الروضة فى ضوء المعايير القوهية لرياض الأطفال}

وعلى الرغم مـن أهميـة اكتسـاب مديري الروضـات المعـارف والمهارات سـابقة الذكر ، والعمل على وضـعها موضـع التطبيق الفعلي بمؤسسـات ريـاض

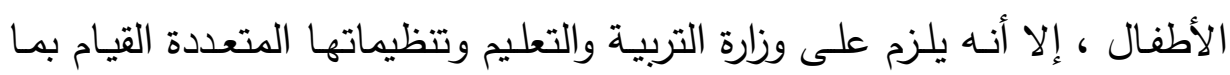
:

- رسم السياسـات والخطط الاسـتراتيجية الواقعيـة بمـا يوجـه الامكانـات الماديـة

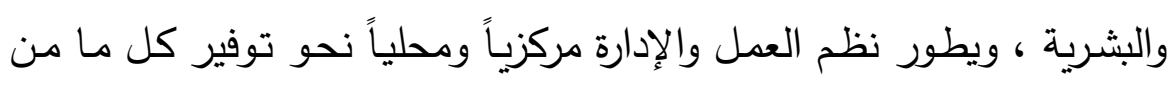

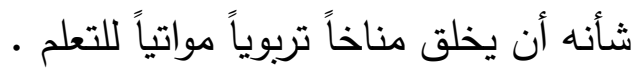

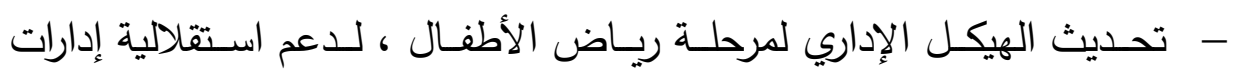
ريـاض الأطفـال على جميـع المستويات ( الـوزارة ، المـديريات ، الإدارات ، الروضات ) ، وفصل ميزانياتها عن ميزانية التعليم الابتدائي • - - دعـم تطبيق اللامركزيـة وزيـادة صـلاحيات مـديري الروضـات مسن النـواحي الإدارية ، وتمكين المديرين من صناعة القرار وتوسيع المشاركة المجتمعية . - - توفير فرص متعددة لمديري مؤسسات رياض الأطفال ، للحصول على تلك الك

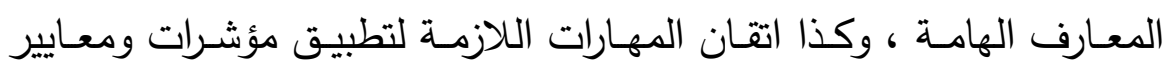

مجال القيادة الفعالة ، ومن بين هذه الفرص :

الدورات التدربية المتخصصة .

البعثات للدول المتقدمة في هذا المجال .

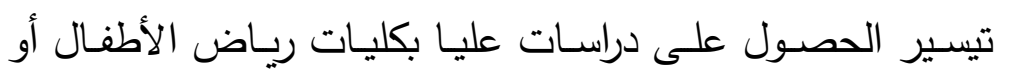

أقسام رياض الأطفال وتربية الطفل بكليات التربية .

$$
\text { المرامج إعداد القادة . الندوات والمؤتمرات . }
$$

إجراء البحوث والدراسات المتخصصة . ... وغيرها . . 
- رفـع الـوعي بـين السـادة مـديري مؤسسـات ريـاض الأطفـال - خاصـة غيـر المتخصصين - بأهمية هذه المرحلة في حياة الطفل ، ومعرفة خصائص نمو لهوبين الطفل ، وسبل دعمها لتحقق أهدافها المرجوة منها .

- الإعداد التربوي المميز لكادر متخصص من معلمات رياض الأطفال ، ليحلوا محل السادة المديرين غير المتخصصين خلال خطة متوسطة المدى لا تزيد

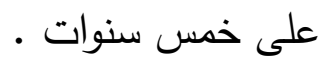

\section{Abstract}

The Ministry of Education approved the National standards document for $\mathrm{KG}$ in 2008, which consists of six areas representing the KG system. One of the most important fields in such a system is effective leadership. However, the KG directors' performance is still traditional and a way from the leadership crateria.

From this standpoint, the study problem can be identified in the following questions:

1) What are the roles, responsibilities and skills the $\mathrm{KG}$ directors need to succeed in the management of $\mathrm{KG}^{\text {? }}$

2) What are the determinants of the $K G$ director professional performance according to the indicators and standards of effective leadership?

3) What is the suggested hypothesis to improve the KG director's performance in the light of effective leadership?

\section{The Methodology:}

This research uses "The Descriptive Analytical Method" as it is appropriate to the nature of the research problem.

\section{The Study Suggestions}

The study presents some proposals for Knowledge and skills necessary for the development of these indicators which make 


\section{تطوير أداء هدير الروضة فى ضوء المعايير القوهية لرياض الأطفال}

them practical in KG. Despite the importance of KG directors' acquiring knowledge and skills, it is necessary for the Ministry of

Education and its various organizations to do the following:

- Setting policies and strategic plans for directing human and material resources.

- Modernizing the administrative structure for kindergarten.

- Supporting decentralization.

- Providing opportunities for $\mathrm{KG}$ director to aquire knowledge and skills nessary for effective leadership such as:

○ Training courses.

○ Scholarships.

○ Post graduate studies.

○ Leadership Development programs.

○ Workshops.

○ Seminars and conferences.

○ Projects.

○ Field visits.

○ Action researches.

- Raising the KG director's awareness of the importance of KG in the child's life.

Preparing a unique KG staff to replace the non-specialist director within a medium-term plan of no more than five years. 
" التغيير إلى الأفضل ... هو نهج واجراءات وآليات يدعمه ... أشخاص

من أصحاب الدافعية المطلوبة " ، هي مقولة تبدو بسيطة في عرضها ولكن عميقة في محتواها ... فقضية البشرية هي محاولة الوصول إلي الأفضل ، ولهذا Kelly, ) كانت هناك الحاجة دائماً إلي إحداث التغيير من حالة إلي حالة . $(2005,11$

والإنسان كائن حي اجتماعي لا يستطيع العيش منفرداً ولا يستطيع الاستغناء عن جهود الآخرين من أجل تسهيل أموره الحياتية ، وكانت حاجته للآخرين سهلة ومبسطة وغير معقدة ، وكلما ازدادت الحياة تعقداً وتحضراً تصبح حاجة الإنسان أكثر إلى الآخرين. (دين، ب99 (14، 74) والإدارة Management وسيلة مهمة لتظيم الجهود الجماعية ، ومن هنا كانت حاجة الإنسان للإدارة ، وهي ضرورية للفرد والجماعة ، فالفرد بحاجة للإدارة لتتظيم وتسيير أموره وأمور أسرته ، والمؤسسة أي مؤسسة بحاجة للإدارة من أجل تتظيم أمورها وتتظيم تفاعل مدخلاتها المختلفة (Edward, 2002, 19)

من هذا المنطلق ، فإن معظم الدول على اختلاف أحوالها تهتم اهتماماً بارزاً بالإدارة بوجه عام والإدارة التربوية بوجه خاص ، لما لها من دور كبير في تقدم المجتمع وازدهاره والنهوض بمستواه في شتى مناحي الحياة ، فلم تعد التربية مجرد مسؤولية من مسؤوليات الدولة تقدمها لأبنائها ، بل أصبح يُنظر إليها علي أنها استثمار بشري حقيقي لله نتائج إيجابية وفعالة تعود بالنفع علي الفرد والمجتمع ، هذا الاستثمار يساعد علي تتمية العنصر البشري وإنتاج المعارف

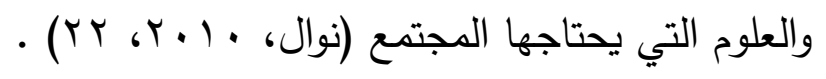




\section{تطوير أداء هدير الروضة فى ضوء المعايير القوهية لرياض الأطفال}

ولقد اتجهت كثير من الدول إلى تطوير العملية التربوية والتعليمية

والنهوض بها عن طريق تطوير المناهج وتزويد المباني بالتجهيزات الضرورية ، هذا بالإضافة إلى إيجاد قيادات تربوية فعالة ومؤهلة تأهيلاً يتناسب مع متغيرات العصـر ومتطلباتـهـ ، ففـي دراسـة حديثـة أعـدها " المجلس الـوطنى للسياسـات الإداريـة التعليميـة " بواشـنطن ، تم تحديث معايير القيادة بالمؤسسـات التعليمية طبقاً للمتغيرات العالمية ، وقد تناولت العديد من المعايير ولكن كان أبرزها ما يتعلق بدور المدير في تطوير الأداء العلمي والتربوي للمتعلمين • (Richard A. and Joseph H., 2008, 1)

فالتربية كعملية استثمار للمجتمع في حاجة ماسة لإدارة فعالة قادرة على قيادة العمل التربوي ، بما يحقق رقي المجتمع ويدفع عجلة التقدم ونموه الاجتماعي والاقتصادي • (Judy D., 2002, 28) ويمثل التعليم والتعلم فى مرحلة رياض الأطفال الأسـاس المتين الذي

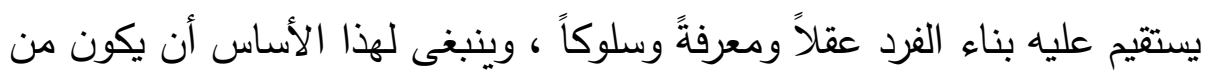
الرسوخ والجودة بمكان ، ومن ثم فإن الإدارة الحكيمة تسهم إسـهاماً أساسياً فى إنجاح العملية التربوية فى مؤسساتتا التعليمية عموماً ، وفي رياض الأطفال على وجه الخصوص ، إذ يتوقف تطور التعليم على وجود منظومة على درجة كبيرة من الكفاءة ، وترسيخ ثقافة عمل تطويرية ، وشيوع روح إيجابية تستطيع مواجهة التحديات بالكفاءة والفاعلية ، ومن هنا يجئ دور مدير الروضـة باعتباره الدور الرئيس لإنجاز هذا الهدف العظيم .

\section{مشكلة البصث :}

تغيرت أهداف الإدارة التربوية في مجال رياض الأطفال حديثاً ، فلم تعد الإدارة تعمل علي تسيير شئون الروضـة وحفظ النظام فيها والتأكد من حضور 


\section{الملة العلمية لكلية رياض الأطفال = جاهعة بورسعيد}

كل العاملين والتزامهم بأعمالهم الموكلة إليهم ، بل أصبح هدفها يرتكز حول

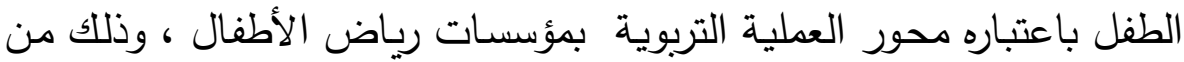
حيث توفير كافة الظروف والإمكانيات التي تساعد على توجيه نموه الجسمي والانفعالي والاجتماعي ... وغيره ، والتي تعمل على تحسين العملية التربوية لتحقيق هذا النمو •

ولقد أقرت وزارة التربية والتعليم عام ^ . . ب وثيقة المعايير القومية لرياض الأطفال ، والتي تتكون من ست مجالات تمثل في مجموعها عناصر منظومة

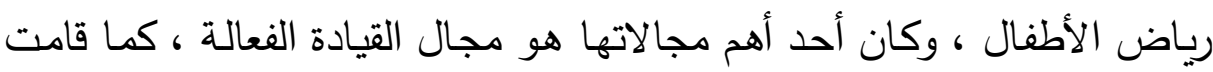
بتدريب عدد كبير من مديري المدارس الابتدائية المشرفين على قاعات رياض الأطفال باعتبارها جزءا من مهامهم الوظيفية ، وعلى الرغم من ذلك فإن شكاوى التيل

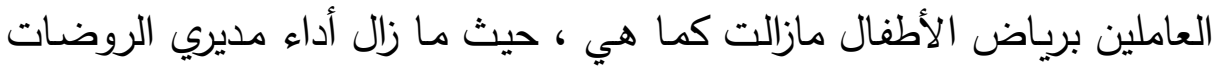

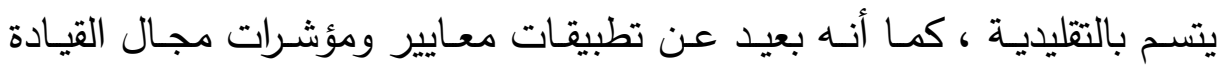

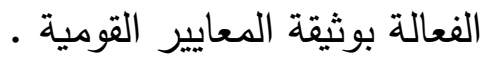

\section{هن هذا المنطلق يمكن تحديد هشكلة الدراسة الحالية هن خلال التساؤلات التالية:}

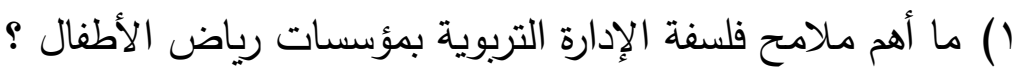

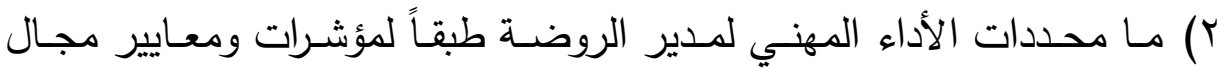
القيادة الفعالة ؟

r) ما مقترحات تطوير أداء مدير الروضة في ضوء مجال القيادة الفعالة ؟ أهداف البحث

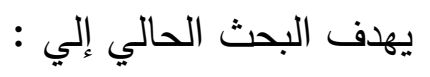

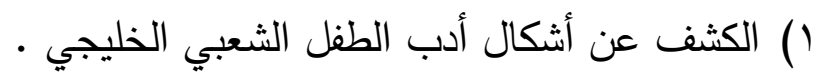

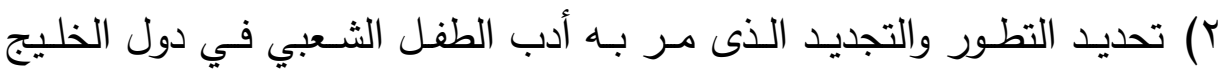

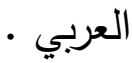




\section{تطوير أداء هدير الروضة فى ضوء المعايير القوهية لرياض الأطفال}

r) عرض نماذج من أشكال ادب الطفل الشعبي الخليجي التي تناقلتها الأجيال

\section{أهميـة البحث}

تسعى الدراسة الحالية لتحقيق الأهداف التالية :

رصد أهم ملامح فلسفة الإدارة التربوية بمؤسسات رياض الأطفال .

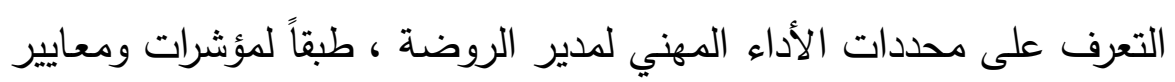

مجال القيادة الفعالة بوثيقة المعايير القومية .

وضع مقترحات تطبيقية تطوير أداء مدير الروضـة ، طبقاً لمؤشرات ومعايير

مجال القيادة الفعالة بوثيقة المعايير القومية لرياض الأطفال .

\section{هنهمج الدراسة : مجهة}

اسـتخدم الباحـث " المـنهج الوصـفى التحليلي " وهـو المـنهج الــي يقـوم

بوصف ما هو كائن وتفسيره وذلك باعتباره المنهج البحثي الملائم لطبيعة مشكلة

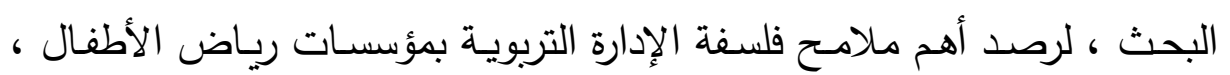
وكذا التعرف على محددات الأداء المهني والتي يجب على مدير الروضة التمكن منها طبقاً لمؤشرات ومعايير مجال القيادة الفعالة بوثيقة المعايير القومية ، وأخيراً تحليل البيانـات والمعلومـات التي تسـهم في وضـع مقترحات لتطوير أداء مدير

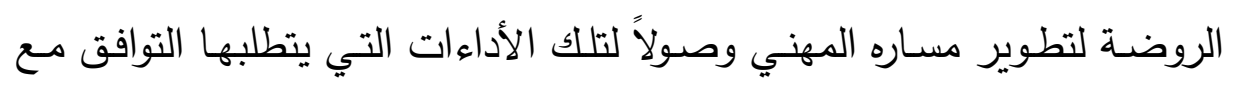
- المعايير

\section{همطالمات البمث}

\section{الإدارة Management}

هـي مجموعـة مـن العمليـات التـي تتفاعل بطريقـة إيجابيـة ضــن منـاخ

مناسب داخل المؤسسة التعليمية في إطار سياسة عامة وقوانين محددة .

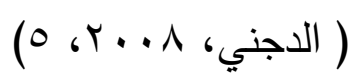


ويعرفها الباحث إجرائياً بأنها : " جميع الجهود والعمليات التي يقوم بها

المدير بمشاركة فريق العمل بالروضة بغرض تتمية الطفل من جميع الجوانب ،

ومساعدته على أن يتكيف بنجاح مع المجتمع " .

\section{القيادة Leadership}

هـي عمليـة دفـع فريـق العهـل لابتكـار الرؤيسة الواضـحة والمشـاركة في

التخطيط والتعاون لتحقيق الأهداف المرجوة ( اليعقوبي، (1) ـ ب، 9 ) .

ويعرفها الباحث إجرائياً بأنها: "القدرة على التأثير الإيجابي في المرؤسين

من خـلال الاتصـال الفعال والحفز والتوجيه، لتهيئة وتتمية روح العمل الفريقي، بما يؤدي لتحقيق الأهداف التربوية المخطط لها بالمشاركة".

\section{القائد The Leader:}

هو من يقود مجموعة العمل برؤية مشتركة وينى الفريق ويحفز الهمح

ليحقق النجاح الجماعى ويدفع الفريق إلى مجالات لم يسبق لهم أن تطرقوا لها ـ

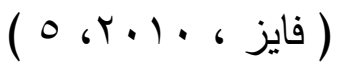

ويعرفه الباحث إجرائياً بأنه : "شخص ذو كاريزما خاصـة، يرشد ويؤثر في

الآخرين ويثير اهتماماتهم ويطلق طاقاتهم ويوجهها في الاتجاه المرغوب، لتحقيق

الأهداف التربوية المخطط لها".

\section{المدير The Manager}

هو الشخص الذي يدير تتفيذ الأعمال الإداريـة فى هيكل منظم، ويوجها

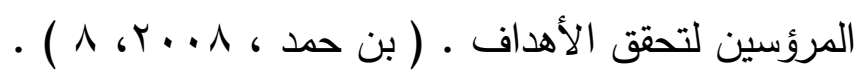

ويعرفه الباحث إجرائياً بأنه : " الشخص المكلف من وزارة التربية والتعليم

بالإشـراف على جميع الشـؤون التربويـة والإداريـة والاجتماعيـة ... وغيرهـا ، كمـا

يؤثر في سلوك وتوجهات مرؤسيه لبلوغ أهداف رياض الأطفال المنشودة " . 


\section{تطوير أداء هدير الروضة فى ضوء المعايير القوهية لرياض الأطفال}

\section{:Standards المعايير}

هـي عبـارات تمثل الحـد الأدنـى مـن التوقعـات المسـتهدفة والمواصـفات

القياسية لكل عنصر من عناصر منظومة التربية في مرحلة رياض الأطفال .

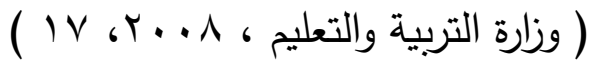

\section{المعايير القوهية لرياض الأطفال KG National Standards:}

هي الوثيقة التي صدرت عن وزارة التربية والتعليم عام ^ ×. . ، ، والتي تحدد

مكونات النظام التربوي لمرحلة رياض الأطفال في جمهورية مصر العربية .

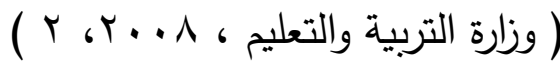

دراسات سابقة:

دراسة Ronald, H. Heck and Philip Hallinger

هدفت هذه الدراسة إلى بحث التطورات المرحلية للدراسات المرتبطة بالقيادة

التربوية ، وأثر ذلك على تحسين أداء العاملين بالمؤسسات التعليمية ، وأظهرت

النتائج أن هذه الدراسـات تركز على شخصية القيادات مع إغفال جوانب أخرى

بما يُضعف نتائج تلك الدراسات، كما تم وضع أدوات محددة تعكس قيود الإطار الواضح للقيادة المفاهيمية ، كما أدت هذه القيود المفاهيمية إلى توجيه الباحثون نحـو اسـتخدام تصــيمات بحـوث ضـعيفة وأدوات إحصــائية لتحليـل البيانـات

- الخاصة بهم

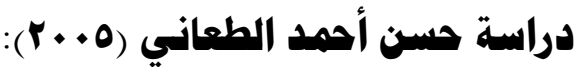

هدفت هذه الدراسة إلى تعرف مصسادر ضغط العمل لدى مديري المدارس

الحكوميـة مـن وجهـة نظرهم ، وكذلك درجـة وجود مصـادر ضـغط العمل لدى

مديري المـدارس الحكوميـة بمحافظــة الكرك بـاختلاف متغيـرات الجنس والخبـرة ومستوى المدارس والتفاعل بينهم ، ومن النتائج التي توصلت إليها الدراسـة أن 
درجـة وجـود مصـادر ضـغط العمـل مرتبـة تنازليـاً هـي : العلاقـة مـع المجتهـع المحلي ، العلاقـة مـع المتعلمين ، العلاقـة مـع القـادة التربويين ، عـدم الرضـا الوظيفي ، التطوير والنمو المهنى ، آلية الصراع ، المشكلات الشخصية لمدير المدرسة . - الم

\section{دراسة Jonas, Haertle}

هـدفت هـذه الدراســة إلى التعـرف على المسـئوليات الرئيسـية للمـديرين

بالمؤسسات التعليمية ، وكذا الالتزامات في عملية مستمرة للتحسين والتطوير ، ونتـج عـن تلك الدراسـة مجموعـة المبادىه الأساسـية ، منهـا : تطـوير قدرات المديرين التربويين ليكونوا مولدات تربوية مستدامة للتعليم ، التدرج في الأنشطة

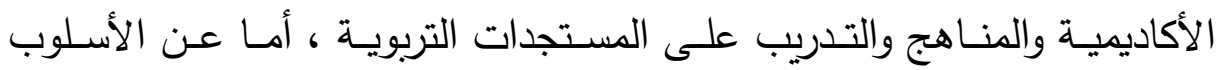
المستخدم فيجب خلق أطر تعليمية ومواد وعمليات وتحسين البيئات التي تقدم خبرات فعالة لتعلم القيادة .

\section{دراسة همد بن هممد هوسى (V) (r):}

هدفت هذه الدراسة إلى تحديد درجة ممارسة مدير المدرسة لدوره في تتمية النمو المهني للمعلمين في المادة العلمية التخصصية ، وكذا تحديد درجة ممارسة مدير المدرسة لدوره في تتمية النمو المهني للمعلمين في استراتيجيات التدريس وكانـت أهـم نتـائج الدراســة أن مـدير المدرسـة يمـارس دوره في النــو المهنى للمعلمين في مجال المادة العلمية بدرجة كبيرة، كما أظهرت أنه يمارس دوره في النمو المهنى للمعلمين في مجال استراتيجيات التدريس بدرجة كبيرة أيضاً.

\section{دراسة Steve, Strand)}

هدفت هذه الدراسـة إلى تحديد مؤشرات الأداء الرئيسية للقيادات المدرسية لتحسـين المؤسسـات التعليميـة ، والعمليـات المرتبطـة بـالتعليم والتعلم في تلك كـ 


\section{تطوير أداء هدير الروضة فى ضوء المعايير القوهية لرياض الأطفال}

المؤسسـات التعليميـة ، ونتج عن هذه الدراسـة وضـع مجموعـة من المؤشرات ، منها : التركيز على النواتج التعليمية والتربوية للمتعلمين ، دعم القيادات التربوية لمؤسساتهم التعليمية ، تقييم انجازات المؤسسة التعليمية من خلال مجموعة من التوقعات تحددها خصائص منها مواظبة المتعلمين مقارنـة بالمعدلات الوطنية ، تحسين المحاسبية مـن خـلال تمكين المسئولين ليسـألوا اسـئلة مرتبطـة بـالإدارة التعليمية .

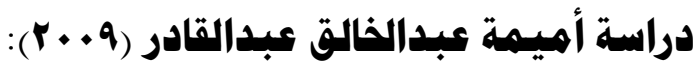

هدفت الدراسة إلى التعرف إلى فاعلية إدارة الوقت وعلاقتها بالأنماط القيادية لدى مديري المدارس الثانوية بمحافظات غزة من وجهة نظرهم ، وذلك من خلال الإجابة عن السؤال الرئيس للدراسة، وهو ما علاقة فاعلية إدارة الوقت بالأنماط القيادية السائدة لدي مديري المدارس الثانوية بمحافظات غزة من وجهة نظـرهم ؟ وجائـت نتـائج الدراسـة على النحـو التـالي : توجـد فـروق ذات دلالــة إحصائية للتقديرات المتوقعة لدرجة فاعلية إدارة الوقت لدى مديري المدارس الثانوية في محافظات غزة من وجهة نظرهم تعزى لجنس المدير في مجال المهام الإداريـة لصـالح الإنـاث ، كمـا توجد فروق ذات دلالــة إحصـائية للتقديرات المتوقعة لدرجة فاعلية إدارة الوقت في مجالي المهام الفنية والشخصية للى مديري المدارس الثانوية بمحافظات غزة من وجهة نظرهم تعزي إلى المؤهل العلمي ( بكالوريوس ، دبلوم عالي ، ماجستير فما فوق ) ·

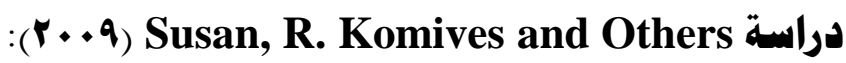
هدفت هذه الدراسة إلى تقويم مدى تطور استراتيجيات القيادة من خلاد

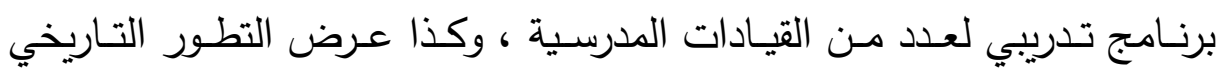

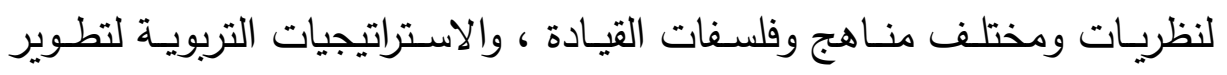
مهارات القيادة التربوية ، وكانت أهم نتائج الدراسة : نقص وعى القيادات التربوية 
المدرسية بنظريات القيادة ، ووجود العديد من التحديات التي تواجه تقييم القيادات المدرسية خاصة أساليب التقييم الكيفي ، وكذا قلة فرص تطوير القيادة التعليمية

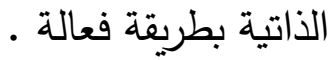

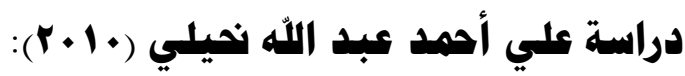

هدفت هذه الدراسـة إلى الكثف عن دور مديري المدرسة في رفع كفاية

المعلمين، وذلك من خلال معرفة آراء مديري المدارس الابتدائية والمتوسطة والثانوية والملتحقين بالدورات التدربية التي عقدتها كلية المعلمين بأبها ، وتوصلت نتائج الدراسة إلى أهمية دور مدير المدرسة في رفع كفاية المعلمين في مجالات البحث المختلفة : العلمية والاجتماعية والإدارية ، وغرس الثقة بالنفس ، والاعتزاز والافتخار بالمهنة ، وإكساب المعلمين المهارات اللازمة في معالجة المشكلات التي تعترضهم ، وفي مجال استخدام طرائق التدريس والوسائل التعليمية الحديثة .

مـن العـرض السـابق للدراسـات السـابقة العربيـة والأجنبيـة ، يتضـح أنهـا تتفق مع اتجاهات الدراسـة الحالية من حيث أهمية الأدور التي يقوم بها مدير المؤسسة التعليمية ، ودراسة خصائص وسمات العملية الإدارية بمؤسسات رياض الأطفال ، وكذا الاهتمـام بتطوير أداء المديرين بما يمكن أن يسهم في تحقيق الأهداف التربويـة لمؤسسـات ربـاض الأطفـال ، باعتباره حجر الزاويـة في إدارة العملية التربوية برياض الأطفال . وفي الصفحات التالية ، سيتم عرض مكونات الدراسة خلال ثلاثة أجزاء ، حيث يتناول الجزء الأول عرض لأهم ملامـح فلسفة الإدارة التزبوية بمؤسسـات ريـاض الأطفال ، ويتناول الجزء الثاني محددات الأداء المهني لمدير الروضـة طبقاً لمؤشرات ومعايير مجال القيادة الفعالة ، وأخيراً وفي الجزء الثالث سيتم عـرض نتـائج الدراسـة الميدانيـة ومـن ثم التصـور المقترح لتطـوير أداء مـدير الروضة طبقاً لمؤشرات ومعايير مجال القيادة الفعالة . 


\section{أولاً: أهم هلاهح فلسفة الإدارة التزبوية بمؤسسات رياض الأطفال}

تعتبر الإدارة التربوية وسيلة مهمة لتنظيم الجهود الجماعية في المؤسسات

التعليمية على اختلافها ، من أجل تتمية المتعلم تتمية شاملة متكاملة ومتوازنـة وفقاً لقدراته واستعداداته وظروف البيئة التي يعيش فيها ، كما يحتاجها المعلم لتسيير أموره وأمور مؤسسته التعليمية ، ومن هنا أصبحت الإدارة ذات أهمية بالغة بالنسبة للمتعلم وللمعلم وغيرهم ممن يعملون في المؤسسة التعليمية بل

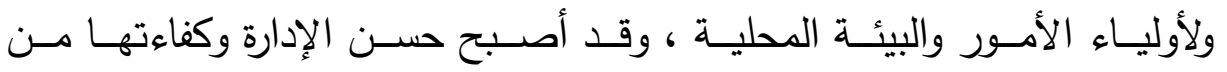

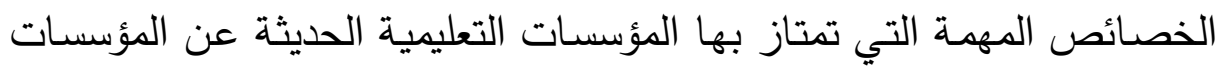
التقليدية .

(Geoff Scott, Hamish Coates \& Michelle Anderson, 2008, 10) والإدارة بمؤسسات رياض الأطفال لم تعد مجرد تسيير شئون الروضـة سيراً روتينياً ، ولم يعد هدف مدير الروضـة المحافظة على النظام ، بل أصبح

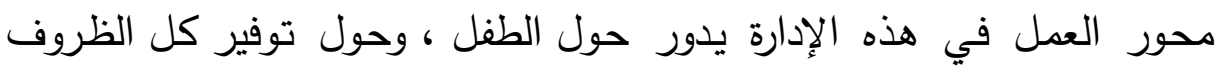
والإمكانيات التي تساعد على توجيه نموه العقلي ، والبدني والروحي ... وغيرها ،

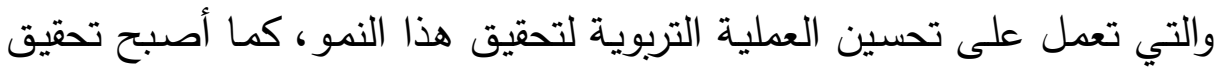
الأهـداف والأغـراض التربويـة والاجتماعيـة حجر الأسـاس في إدارة مؤسسـات

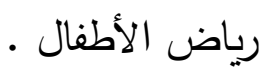

من هذا المنطلق ، سيتم عرض الأدوار والمسئوليات والمهارات الواجب توافرها في مدير الروضة ، للمساهمة في نجاح العملية التربوية بمؤسسات رياض الرداض

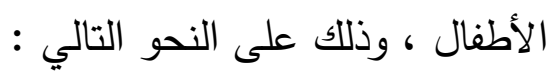

\section{الفروق بين الإدارة والقيادة:}

يـذهب دارسـو الإدارة التربويـة إلـى أن هنـاك فروقـاً بـين مفهومي الإدارة

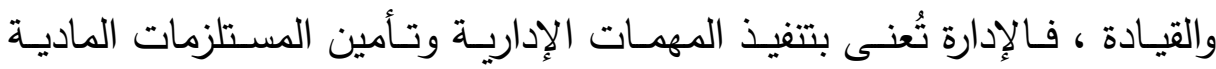

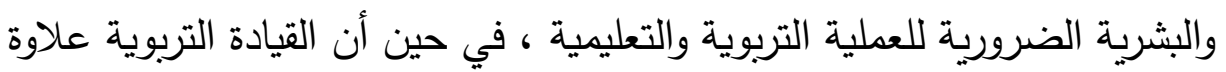
على ذلك تقوم بـأدوار إضـافية ، مثل المشـاركة في رسـم السياسـات التربويـة 
وتتفيـذها ، ووضـع الخطـط والاسـتراتيجيات والمســاهمة في البحـوث العلميـة الإجرائية ، والإصـلاح الدوري للمناهج وأساليب التعليم والتعلم والمتابعـة والتقويم

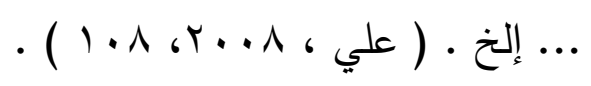

ويتطلب القيام بهذا الدور صقل مجموعة من المهارات القيادية ، وهنالك الكثير من النظريات التي تؤكد هذا الطرح ، ومن هنا فإنه يمكن تحديد الفروق

$$
\text { بين الإدارة والقيادة ، من خلال ما يلي : }
$$

() إن المـدير يُعنـى بالحاضـر ، أمـا القائـد فيهتم ويسـعى باسـتمرار للتطـوير

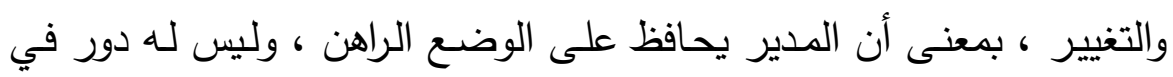

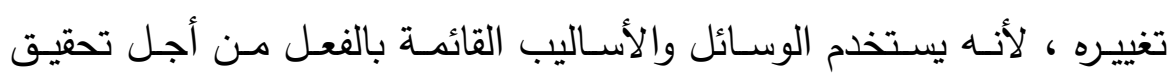
الأهداف والأغراض المقررة بالفعل ، أما القائد التربوي فهو يدعو إلى التغيير

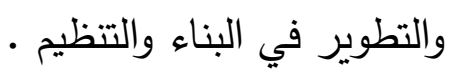

r) الإدارة بالنسبة للمدير تتعلق بالجوانب التنفيذية التي توفر الظروف المناسبة

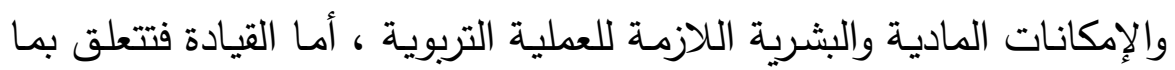
هو أكبر مـن ذلك وتتطلب ممن يقوم بـدورها أن يبتكر ويخطط ويتصور

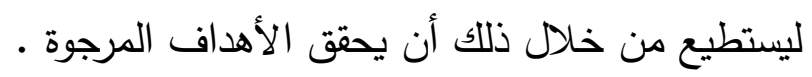

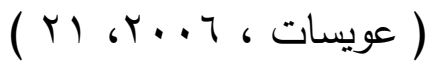

r) إن الإدارة ليست مهارة تأتي مع الزمن عن طريق الخبرة، فالسن والأقدمية في

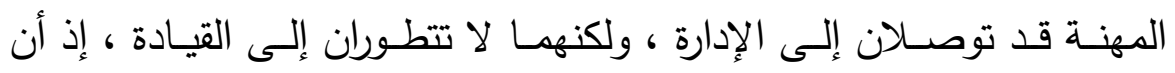

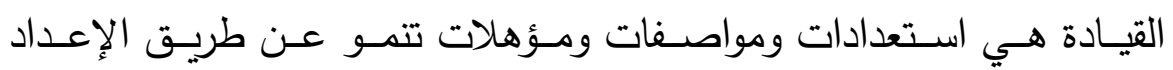

$$
\text { والتدريب . (Barry Z, 2009, 22) }
$$

\section{الصفات والمهارات الواجب توافرها في هدير الروضهة:}

تتطلب وظيفة مدير الروضة توافر مجموعة صفات ومهارات معينة، تشكل

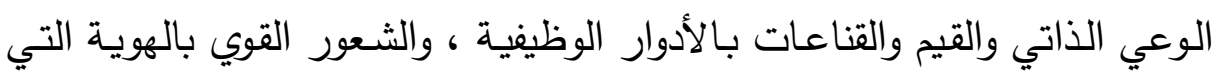
تتوافق مع الدور القيادي ، وكذا الاتساق بين السلوكيات ومعتقدات المدير . (Josep,h F. and Kaitlin, 2009, 74) 
هذه التوليفة من شأنها أن تساعده على القيام بمهامه على أكمل وجه ، نظراً لأهمية الدور القيادي الذي يلعبه مدير الروضة لمؤسسات رياض الأطفال ، لذا فإنه يجب أن تتوفر فيه الصفات والمهارات الآتية : (Michelle, Stephen and Carol, 200727) 
• الخبرة العملية الكافية في مجال التعليم والتعلم برياض الأطفال . • العدل والإنصاف في التعامل مع جميع أفراد فريق العمل بالروضة . . • أن يكون ذو شخصية متزنة ومحببة وجذابة ومؤثرة • الحصول على مؤهل تربوي مناسب .

\section{هـارات الإدارة التزبوية:}

القيادات التربوية في المستويات المختلفة العليا ، والوسطى ، والتنفيذية يجب أن تتمتع بمهارات ثلاث لممارستها الإدارة التربوية ، وهي:

\section{Conceptual Skills همارات فكرية تهرت}

ويُقصد بها القدرة على التفكير المنطقي المرتب، وتصور الأمور ورؤية الأبعاد الكاملة لأي مشكلة ما، وتحديد العلاقات بين المتغيرات المختلفة ، كما أن هنالك علاقة وثيقة بين القيادة ومهارات التفكير النقدي ، ومن أمثلة المهارات الفكرية نذكر : مهارة التخطيط ، مهارة تحليل المشكلات ، مهارة القيادة ، مهارة الإقناع ، مهارة التفاوض ، مهارة اتخاذ القرار · (Nathan, 2009, 133) Human Skills همارات إنسانية ويُقصد بها القدرة على التعامل الفعال الناجح مع الآخرين ، ومن أمثلة المهارات الإنسانية : مهارة الاتصـال مع الآخرين، مهارة كسب الآخرين

$$
\text { واحترامهم . }
$$

\section{همارات فنية Technical Skills}

ويُقصد بها القدرة على القيام بالعمل المطلوب بالشكل السليم ، ومعرفة

تسلسل هذا العمل ، وخطواته ، والإجراءات اللازمة للقيام بالعمل المطلوب ، ومن أمثلة المهارات الفنية : مهارة رصد وتحليل البيانات الدقيقة ، مهارة استخدام الحاسب الآلي ، مهارة كتابة التقارير ، مهارة وضع الميزانيات

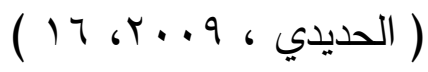




\section{تطوير أداء هدير الروضة فى ضوء المعايير القوهية لرياض الأطفال}

\section{خصائص الإدارة التربهية الناجمة}

أجمـع علمـاء التربيـة والإدارة علـى أن الإدارة التربويــة الناجحـة تتسـم

بمجموعة من الخصائص التي تميزها ، ومن بين هذه الخصائص :

() أن تكون إدارة هادفة : تعتمد علي التخطيط السليم والموضوعية ، لا على

العشوائية والصدفة في تحقيق أهدافها .

r) أن تكون إدارة ايجابية : وهذا يؤكد علي الدور القيادي في مجالات العمل

وتوجيهاه ، ولا تركن إلي الجمود والسلبية .

r) أن تكون إدارة اجتماعية : بمعنى أن تبتعد الإدارة عن الاستبداد والتسلط ، وتكـون قائمـة علي التشـاور والتعـاون والألفــة وإقامـة جسـور الثقـة والمحبـة والاحترام المتبادل بين العاملين •

ع) أن تكون إدارة مرنة : ينبغي أن تتصف الإدارة بالمرونة دون إفراط أو تفريط ، ولا يتجاوز عند التعصب لرأي أو مذهب أو نظرية تربوية معينة .

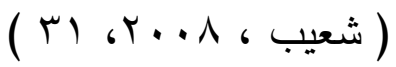

\section{عناصر العماية الإدارية}

التخطيط Planning هو عملية ذكية وتصرف ذهني لعمل الأشياء بطريقة منظمة للتفكير قبل العمل ، والعمل في ضوء الحقائق بدلاً من التخمين . التنظيم Organization هو تقسيم العمل إلى عناصر ومهمات ووظائف ، وترتيبها في علاقات سليمة ، وإسنادها إلى أفراد بمسؤوليات وسلطات تسمح بتفيذ سياسات المنظمة . التوجيه Guidance هو الكيفية التي تتمكن بها الإدارة من مواجهة الفروق الفردية في بيئة العمل ، وتحقيق التعاون بين العاملين وحفزهم للعمل بأقصى طاقاته ، مع توفير البيئة الملائمة لإشباع حاجاتهم وتحقيق أهدافهم • 
الرقابة Monitoring هي الإشراف والمتابعة من سلطة أعلى، بقصد معرفة كيفية سير الأعمال ، والتأكد من أن الموارد المتاحة تستخدم وفقاً للخطة

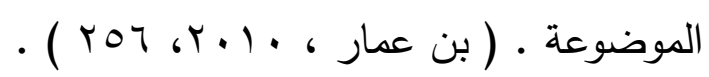

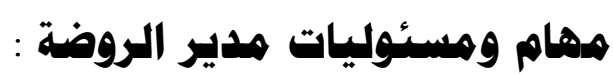

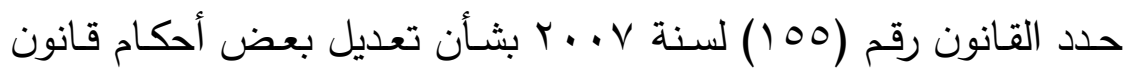

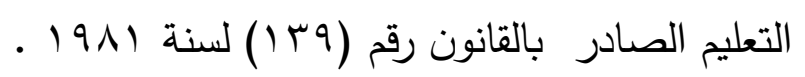

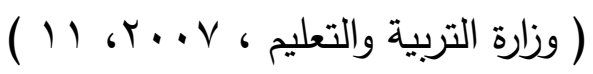

مادة (V) : أن يكون اختيار شاغلي وظيفة مدير الروضة من بين شاغلي

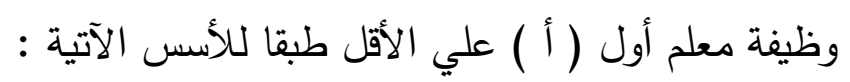

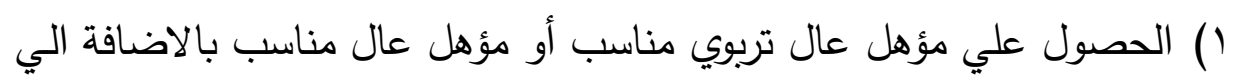

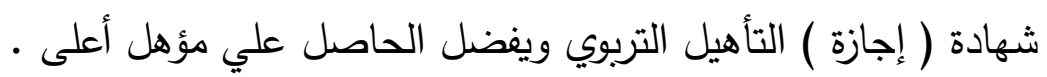
r) قضاء مدة أربع سنوات علي الأقل في وظيفة معلم أول ( أ ) .

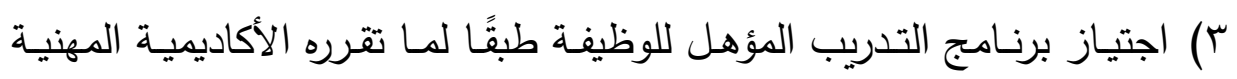
- للمعلمين

ع) توافر السمات الشخصية من حيث الكفاءة والجدارة من واقع الملفات والجوانب الأخلاقية والمهنية والثقافية التي تؤهله لشخل الوظيفة .

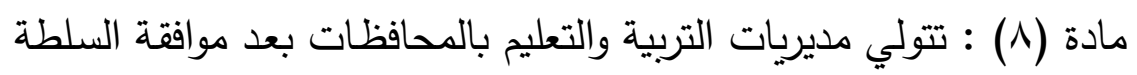

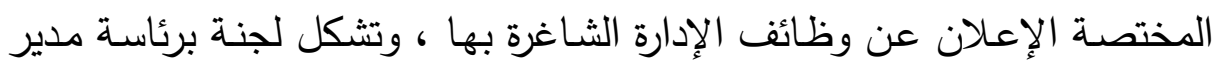
المديرية تضم عناصر فنية وقانونية وإدارية تتولي الاختيار من بين المتقدمين في ضوء الأسس المنصوص عليها في المادة السابقة . مادة (1) (1) : تتحدد المعايير الملزمة للأداء التعليمي لوظائف الإدارة علي النحو التالي :

\section{همال الثقافة المؤسسية :}

رؤيسة خطط وأسـاليب واضـحة للتعليم ، وبيئة تتظيميـة ميسـرة للتواصـل • الإنساني 


\section{تطوير أداء هدير الروضة فى ضوء المعايير القوهية لرياض الأطفال}

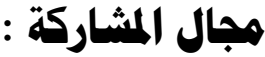

الالتزام بقيم ومبادئ التشاور لدعم العمل الجماعي وتوسيع فرص ومجالات الحوار والمناقشة وتبادل الآراء والأفكار ، والتوظيف الفعال لتكنولوجيا المعلومات في تيسير تداول المعلومات ونشـرها وصنع اتخـاذ القرارات الرشيدة في تطوير التعليم والمشاركة المجتمعية .

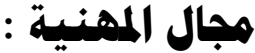

الـتمكن المعرفي ، والـتمكن المهــاري ، والتتميــة المهنيــة المسـتديمة ،

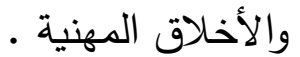

\section{هجال إدارة التغيير : - مجير}

مناخ تنظيمي داعم للتغيير الإبداعي ، وتغيير تربوي يرتكز علي المبادرة وتثـيع التجريب والتجديد ، وتبني المداخل العلميـة في تعبئة الأفراد وتحفيز ئريز الجهود وتيسير عمليات التغيير وإعداد خطط تقويم وتطوير المدرسة ، والمشاركة في متابعتها وتنفيذها تمهيداً للاعتماد التربوي . ممـا سبق يتضـح أن مدير الروضــة هو المسئول عن تخطيط وتتظيم

وتتسيق ومتابعة وتقويم جهود العاملين في الروضة من أجل تحقيق أهدافها . ويعتبر مدير الروضة مسئولاً عن الناحيتين الإداريـة والفنية في الروضـة ، فهو يصبح إدارياً عندما يهيىء كل ما تتطلبه عمليات التعليم والتعلم من أدوات ومساعدات ، كما أنه يصبح مشرفاً فنياً عندما يقوم بكل الخدمات الضرورية لتهيئة تعليم جيد فعّال . ثانيًا: همددات الأداء لمدير الروضة طبقًا لمؤشرات ومهايير همال القيادة | الفعالة

تعتبر وثيقـة المعـايير القوميـة لريـاض الأطفـال امتداداً للمعـيير القوميـة للتعليم في مصر التي صدرت وثيقتها في عام ب . . r ، والتي أسس صدورها لعهد جديد يتم فيه التعامل مع قضايا التعليم وشئونه من منظور استراتيجي يركز 
على الجودة والمحاسبية. وتأتي أهمية بناء معايير قوميـة لرياض الأطفال في

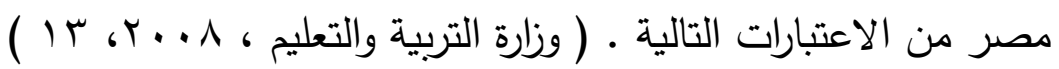
الأول : التطلع إلى مد مظلة ضمان الجودة والاعتمـاد لتشمل مؤسسـات ريـاض

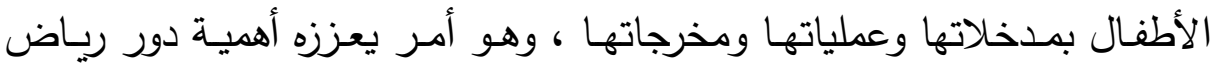

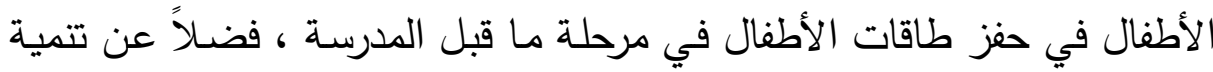

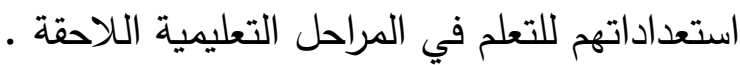
الثـاني : خصوصية مرحلة رياض الأطفال التي تميزها عن غيرها من مراحل التعليم قبل الجامعي من حيث الأهداف ، وطبيعة المتعلمين ، ومحتوى البرنامج التعليمي وأساليب التعليم والتعلم ... وهو ما استلزم بناء معايير قومية تراعي تلك لتك

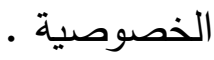

الثالث : الإفادة من الخبرات المتراكمة عن التعامل مع المعايير القومية للتعليم على مستوى الفكر والتطبيق معاً ، فقد تكونت في مصر كوادر بشرية وخبرات عملية نتيجة المشاركة في بناء وتطوير المعايير القومية للتعليم في مصر • الرابع : مراعاة المتغيرات والمستجدات على الساحة التربوية التي لم تكن موجودة

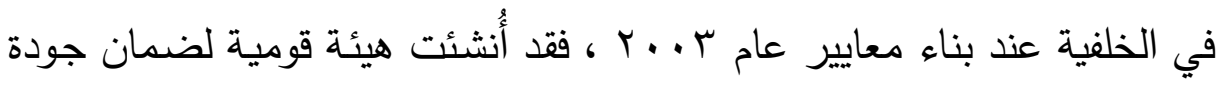
التعليم والاعتماد بناءً على قرار رئيس الجمهورية رقم Oب لسنة V . . Y ، واعتمد

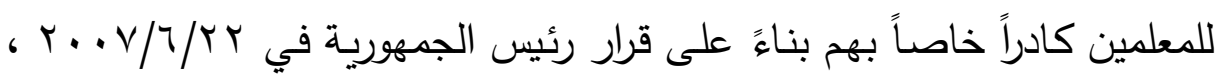

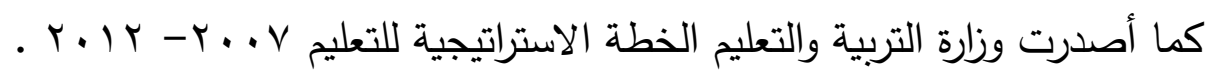
وتخاطب معايير رياض الأطفال فئات متعددة تمثل في مجموعها المعنيين بها؛ فقد اشـتملت وثيقـة المعـايير القوميـة على عـد مـن الوثائق الفرعيـة بلـن مجموعها ست وثائق ( نواتج التعلم ، محتوى المنهج ، معلمة الروضـة ، القيادة الفعالة والتوجيه التربوي ، المشاركة المجتمعية ، الروضـة الفعالة ) ، وكل وثيقة منها تتعامل مـع مكون من مكونـات التربية في مرحلـة ريـاض الأطفال ، وكل وثيقة تتفرع إلى مجالات ، ثم إلى معايير ومؤشرات . 


\section{تطوير أداء هدير الروضة فى ضوء المعايير القوهية لرياض الأطفال}

وفي هذا الإطار ، تُعد القيادة التربوية عنصراً حاسماً يدفع باتجاه تطوير العمليـة التعليميـة في مختلـف مراحلهـا ، كمـا يمثل القـادة علـى المسـتوين الاستراتيجي والتنفيذي قوة الدفع الرئيسية لعملية التغيير وإنجاز أهداف تطوير • التعليم

كمـا تُسـهم القيـادة إسـهاماً أساسـياً ومحوريـاً في إنجـاح العمليـة التربويـة بالمؤسسات التعليمية بوجه عام وبمؤسسات رياض الأطفال بوجه خاص ، حيث يتوقف تطورها على كفاءة منظومة القيادة وشيوع روح إيجابية تستطيع مواجهة التحديات بالكفاءة والفعالية المطلوبين .

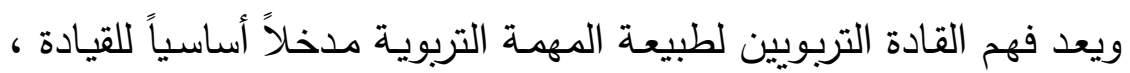
ذلك أن القائد التربوي يلعب دوراً محوريـاً في تحديد أهداف تلك العملية ، وفي رسم الطرق وتحديد الوسائل التي من شأنها إنجاز هذه الأهداف . وتسعى وثيقة مجال القيادة التربويـة بالمعايير القومية إلى رسم محددات

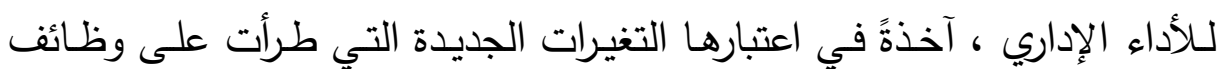

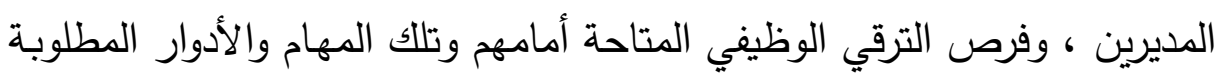

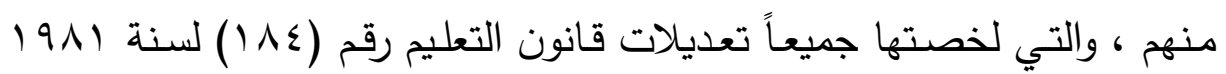

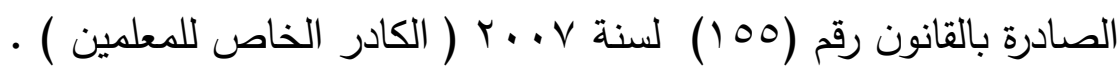
وقد قُسمت الوثيقة إلى ، أولاً : مجال ومعايير القيادة الفعالة ، ثانياً : مجال ومعايير التوجيه التربوي ، وباعتبار أن الدراسة الحالية تركز على أداءات مديري الروضـات ، فسيتم عرض معايير ومؤشرات مجال القيادة الفعالة ، وذلك على

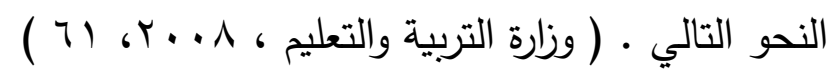

\section{هؤشرات المعيار الأول : ترسيخخ الثقافة المؤسسية}

يعمل القائد على نشر الوعي بالرؤية المستقبلية للتعليم في مصر • يوفر الإمكانيات اللازمة لإنجاز الأهداف القومية للتعليم برياض الأطفال. • يستخدم الأساليب الحديثة في التخطيط والإدارة . 


\section{المبلة العلمية لكلية رياض الأطفال = جامعة بورسعيد}

• بطبق الأساليب الحديثة في المتابعة والتقويم •

• يرصد المشكلات التي قد تؤثر في تحقيق الأهداف الاستراتيجية ويشارك

$$
\text { في حلها - في }
$$

• يطلع على أحدث التطورات في مجال التربية في مرحلة رياض الأطفال .

\section{هؤشرات المعيار الثاني : دوم التشاور والمشاركة}

$$
\text { يرسخ القائد مبدأ التشاور والعمل في فريق • }
$$

• يوفر سبل الحصول على المعلومات وتيسير تداولها •

• يشرك العاملين في وضع الخطط واتخاذ القرارات .

• يوسع فرص مشاركة المجتمع المدني في دعم مؤسسات رياض الأطفال . هؤشرات المعيار الثالث : الترام الأخلاقيسات والقواعد المهنية

• يوظف القائد قدرات ومهارات العاملين لخدمة أهداف العمل .

• يطبق أسلوب العمل في فريق والقيادة الجماعية .

$$
\text { • يستند في قراراته إلى معلومات موثقة ودقيقة . }
$$

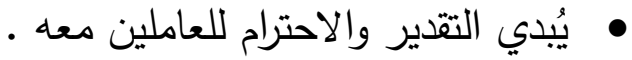

\section{هؤشرات المهيار الرابع: تشجيع المبادأة وإدارة التغيير}

• يشجع القائد على التجريب والتجديد في بيئة العمل •

• يستخدم الأساليب الحديثة في تعبئة الأفراد وحفز الجهود .

• يحرص على تفويض السلطات وخلق كوادر للتغيير

يتقبـل الأفكـار والآراء ويسـتثرها لتطــوير العمـل بمؤسسـات ريـاض

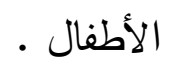

وتأسيسـاً على مـا سـبق ، يجدر بنـا هنـا أن نسـأل : مـا هـي المعـارف

الأساسية والمهارات المطلوبـة لتحقيق هذه المؤشـرات ؟ ، والتي أصبحت منذ 
اعتماد وزارة التربية والتعليم لوثيقة المعايير ، عقداً ملزماً للسادة مديري الروضات بعدوم جمهورية مصر العربية ، وهل لاى مديري الروضـات وعي بهذه المعارف والمهارات ؟ ، وهل لايهم من القدرات العقلية والنفسية ما يؤهلهم للنجاح في أداء المهام المستحدثة التي وردت في كثير من المؤشرات ؟ ، وما التصور المقترح الأي قد يُسهم في الإجابة على تللك التساؤلات ؟ . وسيتم خـلال الصفحات التاليـة الإجابـة على هذه التسـاؤلات الهامـة مـن خلال عرض نتائج الدراسة الميدانية ، ومن ثم وضع مقترحات لتطوير أداء مدير الروضة في ضوء المعايير القومية لرياض الأطفال ، وذلك على النحو التالي :

\section{ثالثًا: الدراسة الميدانية}

استخدمت الدراسة المنهج " الوصفي التحليلي" لجمع المعلومات والحقائق والبيانـات خـلال الإطار النظري للدراسـة ، ومن ثم استطلاع رأي عينـة الدراسـة وتحليلها وتفسيرها وفقاً لإجراءات الدراسـة الميدانية ، ثم وضـع مقترحات تطوير أداء مدير الروضة فى ضوء المعايير القومية لرياض الأطفال . عينة الدراسة :

تتكون عينـة الدراسـة مـن مديري ريـاض الأطفـال مـن بعض محافظـات

جمهوريـة مصر العربية ( الاسكندرية ، الدقهلية ، بورسعيد ، الفيوم ، المنيا ) ، وعددهم (Y0) مديراً ، وتم استخدام الإحصـاء الوصفي والذي يمثل التكرارات والنسب المئوية لوصف عينة الدراسة ، على النحو التالي : جدول رقم (1) توزيع عينة الدراسة وفقًا لطبيعة العهل

\begin{tabular}{|c|c|c|}
\hline النسبة المئوية & 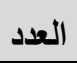 & المسمى الوظيفي \\
\hline$\%$ ะ & 11 & مدير مدرسة ابتدائية مشرف على الروضة \\
\hline$\%$ \% & 1 & مدير رياض الأطفال \\
\hline$\% r r$ & $\wedge$ & قائم بعمل مدير رياض الأطفال \\
\hline$\% 1 \ldots$ & ro & الإجمالي \\
\hline
\end{tabular}


المجلة العلهية لكلية رياض الأطفال = جاهعة بورسعيد

جدول رقم (ז) توزيع عينة الدراسة وفقاً للمؤهل الدراسي

\begin{tabular}{|c|c|c|}
\hline النسبة المئوية & 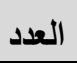 & المؤهل الدراسي \\
\hline$\% \circ 4$ & $1 \leq$ & بكالوريوس رياض أطفال \\
\hline$\%$ & 9 & مؤهل تربوي غير متخصص في رياض الأطفال \\
\hline$\% \wedge$ & r & مؤهل غير تربوي \\
\hline$\%$ & ro & 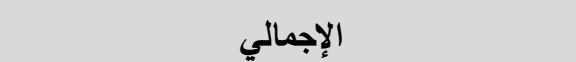 \\
\hline
\end{tabular}

جدول رقم (ז) توزيع عينة الدراسة وفقاً لعدد سنوات الخبرة في الإدارة

\begin{tabular}{|c|c|c|}
\hline النسبة المئوية & العدد الع & عدد سنوات الخبرة \\
\hline$\%$ r $\leq$ & 7 & أقل من r سنوات \\
\hline$\% \leqslant \leqslant$ & 11 & من ب سنوات لأقل من • سنوات \\
\hline$\% r r$ & $\wedge$ & من • سنوات فأكثر \\
\hline$\% 1 \ldots$ & ro & الإجمالي \\
\hline
\end{tabular}

\section{أدة الدراسة الميدانية :}

تم بناء استبانة مكونة من ( • 9) بنداً في أربعة محاور رئيسية، بالاستعانة بالأدبيات الواردة في الإطار النظري وكذا الدراسـات السـابقة ، ولقد تم استخدام مقيـاس (ليكرت الثلاثى ) لتحديـد درجـة الأهميـة بحيث تعطى الدرجـة (ب) للاسـتجابة كبيـرة ، الدرجـة (ץ) للاسـتجابة متوسـطة ، الدرجـة ( () للاسـتجابة ضعيفة ، وبناءً على ذلك تم استخدام المعيار التالي للحكم على قيم المتوسطات

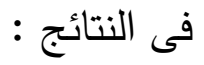

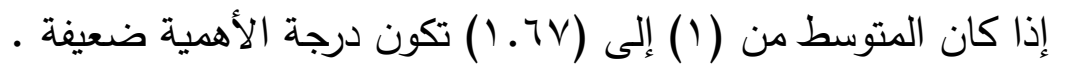

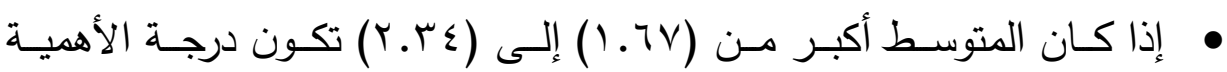
متوسطة .

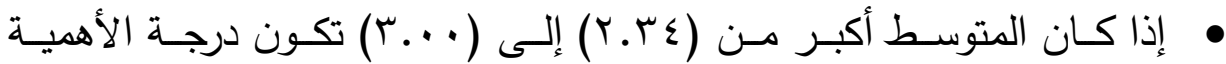

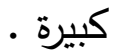




\section{صدق وثبات أداة الدراسة}

أولاً: صدق الأداة :

يشير مفهوم الصدق إلى الاستدلالات الخاصة التى نخرج بها من درجات

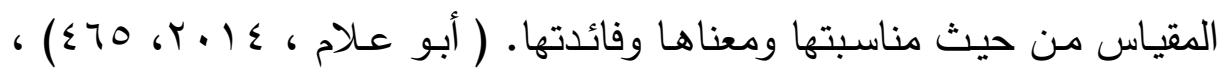
ولقد قام الباحث بالتأكد من صدق الاستبانة من خلال ما يلى :

صدق المكمين :

تم عـرض الأداة في صـورتها الأوليـة على عـد مـن السـادة المحكمين المتخصصين في مجال تربية الطفل والإدارة ، وكذا عدد من المديرين بمؤسسات

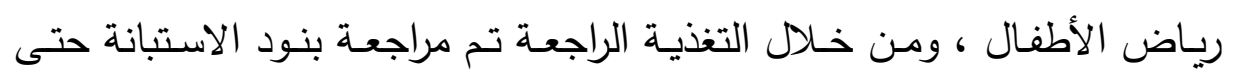
خرجت في صورتها النهائية ، وذلك على النحو التالي :

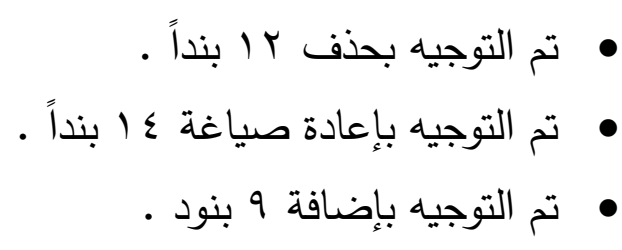

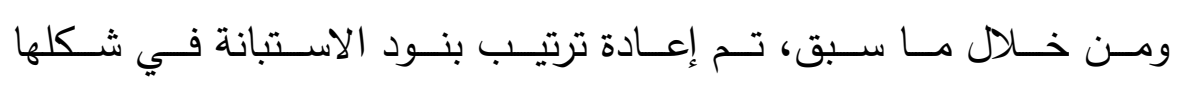
- النهائي

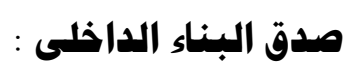

يشير إلى " الإرتباطات العالية بين مجموع الدرجة الكلية للاختبار والأبعاد الفرعيـة التى تقيس السـة نفسها تدعم الصدق وتؤكده ، حين يتتم التحقق من صـدق الاختبـار بطرق أخرى ، ويفترض هذا الصـدق كون الإختبار منطقياً ومتجانساً فى قياس السمة المقاسة (Gronuld, 1981, p12)، وقد قام الباحث

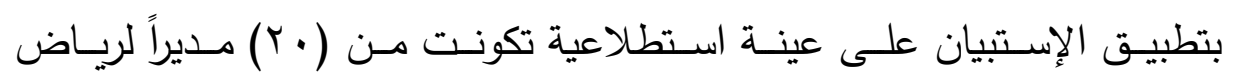
الأطفال ، ثم استخدم الباحث معامل ارتباط " بيرسون " فى حساب مدى الارتباط

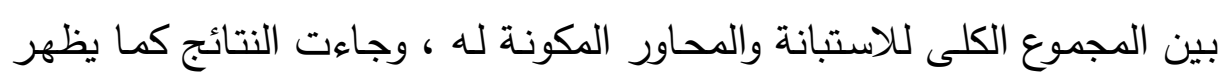

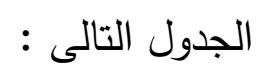


جدول (₹) نتائج صدق البناء الداخلى لحاور الإستبيان (ن= •r)

\begin{tabular}{|c|c|c|c|c|}
\hline \multicolumn{2}{|c|}{ المهارات المطلوبة } & \multicolumn{2}{|c|}{ المعارف الأسساسية } & \multirow{3}{*}{ المعايير } \\
\hline 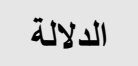 & 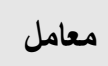 & 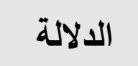 & 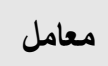 & \\
\hline الإحصائية & الارتباط & الإحصائية & الارتباط & \\
\hline$\ldots 1$ &.$\wedge v Y$ & $\ldots 1$ &.$\wedge r$ & المحورالأول: ترسيخ الثقافة المؤسسية \\
\hline$\ldots 1$ & ו & $\ldots 1$ & $. v \leqslant \wedge$ & المحور الثانى: دعم التشاور والمشاركة \\
\hline$\ldots 1$ &.$V r \varepsilon$ & $\ldots 1$ & 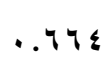 & المحور الثالث: التزام الأخلاق والقواعد المهنية \\
\hline$\cdots 1$ &. $.4 \wedge \wedge$ & $\ldots 1$ &. & المحور الرابع: تشجيع المبادأة وإدارة التغيير \\
\hline
\end{tabular}

يتضـح مـن الجـدول (ع) أن معـاملات الارتبـاط بـين محساور المعـارف الأساسية والدرجة الكلية للاستبانة تراوحت بين (r آ . .- ابی. • ) ، فى حين أن معـاملات الارتباط بين محاور المهارات المطلوبـة والدرجـة الكليـة للاستبانة

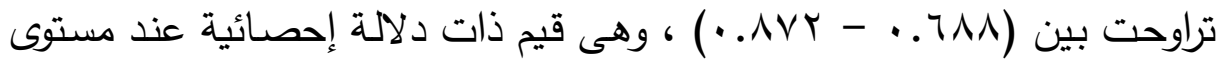
الدلالة ( ( . . ) ، مما يؤكد على أن جميع محاور الاستبانة تتمتع بصدق البناء

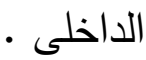

\section{ثانيًا: ثبات الأداة}

ويُقصـــد بالثبـات : " أن يعطـى المقيـاس النتـائج نفسـها إذا أعيد على

المجموعـة نفسها وفى الظروف نفسها وهو من الصفات المرغوب توافرهـا فى

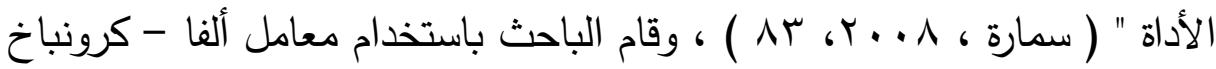
(a) لحساب ثبات المحاور والدرجة الكلية للاستبانة مستعيناً فى ذلك بالبرنامج الإحصـائى (SPSS) للبيانـات التى حصـل عليهـا مـن العينـة الاسـطلاعية ، وجاءت النتائج كما يوضح فى الجدول التالى : 


\section{تطوير أداء هدير الروضة فى ضوء المعايير القوهية لرياض الأطفال}

\section{جدول (0) نتائج ثبات الاستبانة بطريقة ألفا- كرونباخ (ن= + r)}

\begin{tabular}{|c|c|c|c|c|}
\hline \multicolumn{2}{|c|}{ 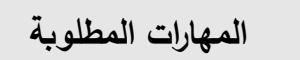 } & \multicolumn{2}{|c|}{ المعارف الأساسية } & \multirow{3}{*}{ 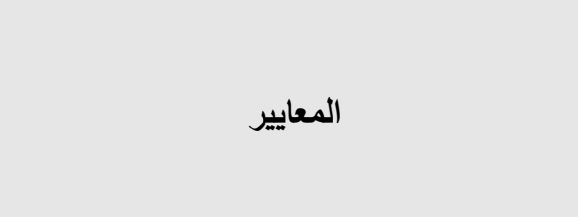 } \\
\hline 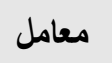 & & 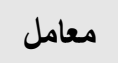 & عدد & \\
\hline الثبات & المؤشرات & الثبات & المؤشرات & \\
\hline. .179 & 19 & $\cdots \wedge \leq 0$ & 17 & المحور الأول: ترسيخ الثقافة المؤسسية \\
\hline$\cdot v \wedge r$ & 1. & $\cdot . \wedge \cdot 7$ & 11 & المحور الثانى: دعم التشاور والمشاركة \\
\hline . Arr & 9 & $\because$. VTV & $\wedge$ & المحور الثالث: التزام الأخلاق والقواعد المهنية \\
\hline$\cdot \wedge 01$ & 9 & $\because \vee \wedge 1$ & $\Lambda$ & المحور الرابع: تثجيع المبادأة وإدارة التغيير \\
\hline$\cdot 9 \cdot r$ & $\varepsilon V$ & . & $\varepsilon r$ & الدرجة الكلية للاستبانة \\
\hline
\end{tabular}

يتضـح من الجدول (0) أن معاملات الثبات لمحاور المعارف الأساسية

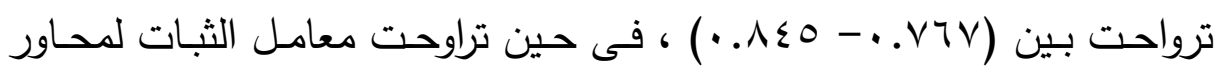

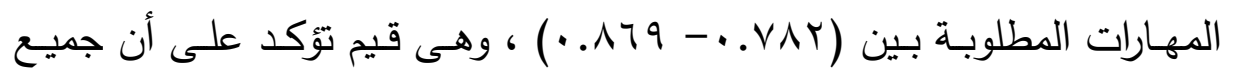
محاور الاستبانة تتمتع بدرجة مرتفعة من الثبات، كما بلـغ معامل الثبات العام للمعارف الأساسية (ז7^. • ) ، بينما بلـخ معامل الثبات العام للمهارات المطلوبة ( ( . . • ) ، وهى قيم تؤكد أيضاً على أن الاستبانة ككل تتمتع بدرجة مرتفعة من

\section{تصليل النتائج وتفسيرها :}

قام الباحث بحساب الإحصاءات الوصفية لاستجابات العينة على استبانة الإدارة بالبيانات ، وسيعرض الباحث كلاً من النتائج الإجمالية والنتائج التفصيلية التى توصل اليها ، وذلك على النحو التالي : 


\section{( أ ) النتائج الإجمالية لإستجابات العينة على الإستبانة}

\section{جدول (1) النتائج الإجمالية لإستجابات العينة هن مديري رياض الأطفال على الإستبانة (ن= (†O)}

\begin{tabular}{|c|c|c|c|c|c|c|c|c|c|}
\hline \multicolumn{4}{|c|}{ المهارات المطلوبة } & \multicolumn{4}{|c|}{ المعارف الأساسية } & \multirow[b]{2}{*}{ المعاييز } & \multirow[b]{2}{*}{$\frac{\overline{3}}{3}$} \\
\hline 雲: & 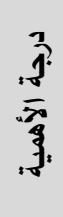 & $\begin{array}{l}\overline{7} \\
3 \\
\overline{3} \\
\overline{3} \\
\frac{3}{3}\end{array}$ & $\begin{array}{l}\frac{9}{1} \\
\overline{3} \\
\overline{3} \\
\frac{3}{3} \\
\frac{3}{3}\end{array}$ & 牙: & 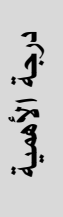 & $\begin{array}{l}\overline{7} \\
\frac{7}{7} \\
\overline{7} \\
\frac{3}{3}\end{array}$ & $\begin{array}{l}\frac{9}{1} \\
\overline{3} \\
\frac{3}{3} \\
\frac{3}{3}\end{array}$ & & \\
\hline o & 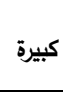 & $r . \varepsilon r$ & $\varepsilon$ & $\varepsilon$ & 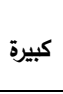 & r. $\leqslant 9$ & $\varepsilon$ & مصر القائد على نشر الوعى بالرؤية المستقبلية للتعليم فى & 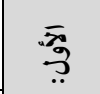 \\
\hline$r$ & 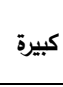 & r.OY & r & $r$ & 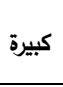 & r.01 & $r$ & رياض الأطفال & 预 \\
\hline 1 & كبيرة & r.00 & • & $r$ & كبيرة & r.०s & $\varepsilon$ & يستخدم الأساليب الحديثة في الإدارة والتخطيط & \\
\hline$r$ & كبيرة & Y.० & • & 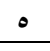 & 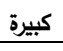 & r. & $r$ & يطبق الأساليب الحديثة في المتابعة والتقويم & 天 \\
\hline$\varepsilon$ & 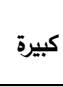 & r. $\varepsilon v$ & $r$ & 1 & 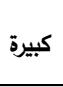 & r.v. & $r$ & 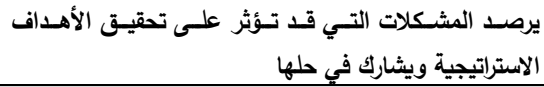 & \\
\hline \multicolumn{2}{|c|}{ بدرجة كبيرة } & ro. & 19 & \multicolumn{2}{|c|}{ بارجة كبيرة } & r.or & 17 & \multicolumn{2}{|l|}{ المتوسط العام للمحور الأول } \\
\hline$\varepsilon$ & كبيرة & r.or & $r$ & $r$ & 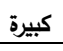 & Y.\& V & $r$ & يرسخ مبدأ التشاور والعمل في فريق & \multirow{4}{*}{ 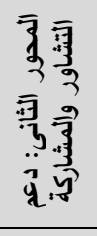 } \\
\hline$r$ & 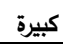 & Y.04 & $r$ & $r$ & 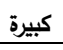 & r. $\leqslant V$ & $r$ & يوفر سبل الحصول على المعلومات وييسر تداولها & \\
\hline r & 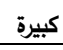 & r.T\& & $r$ & $r$ & 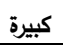 & r.or & $r$ & يشرك العاملين في وضع الخطط واتخاذ القرار & \\
\hline 1 & كبيرة & r.T4 & r & 1 & كبيرة & Y.TV & $r$ & رياض الأطفال مشساركة المجتمع المدني في دعم مؤسسـات & \\
\hline \multicolumn{2}{|c|}{ برجة كبيرة } & r.०1 & 1. & \multicolumn{2}{|c|}{ بدرجة كبيرة } & r.or & 11 & \multicolumn{2}{|l|}{ المتوسط العام للمحور الثانى } \\
\hline 1 & كبيرة & r.Vr & $r$ & $r$ & 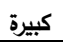 & r.१. & r & يوظف القائد قدرات ومهارات العاملين لذدمة أهداف العمل & $\bar{j}$ \\
\hline r & كبيرة & r.१^ & $r$ & $r$ & كبيرة & Y.४. & r & يطبق أسلوب العمل في فريق العمل والقيادة الجماعية & \\
\hline r & كبيرة & r.१1 & $r$ & 1 & 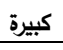 & r.v५ & $r$ & يستند في قراراته إلى معلومات موثقة ودقيقة & $\Rightarrow$ \\
\hline$r$ & 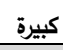 & r.tr & $r$ & r & 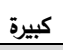 & ץ.१५ & $r$ & يبدى التقدير والاحترام للعاملين معه & \\
\hline \multicolumn{2}{|c|}{ بلرجة كبيرة } & Y.१^ & 9 & \multicolumn{2}{|c|}{ بدرجة كبيرة } & r.74 & $\wedge$ & \multicolumn{2}{|l|}{ المتوسط العام للمحور الثالث } \\
\hline$r$ & 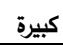 & r.04 & $r$ & $\varepsilon$ & 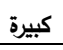 & r.०s & $r$ & يثجع القائد على التجريب والتجديد في بيئة العمل & \multirow{4}{*}{ 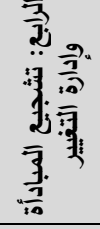 } \\
\hline 1 & كبيرة & r.v. & $r$ & 1 & 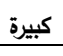 & r.v. & $r$ & يستخدم الأساليب الحديثة في تعبئة الأفراد وحفز الجهود & \\
\hline$\varepsilon$ & كبيرة & r.os & $r$ & $r$ & كبيرة & r.Y. & $r$ & يحرص على تفويض السلطات وخلق كوادر جديدة & \\
\hline r & كبيرة & r. 4. & $r$ & r & كبيرة & T.Tr & $r$ & رياض الأطفال & \\
\hline \multicolumn{2}{|c|}{ بدرجة كبيرة } & ч.४. & 9 & \multicolumn{2}{|c|}{ بدرجة كبيرة } & r.Tr & $\wedge$ & \multicolumn{2}{|l|}{ المتوسط العام للمحور الرابع } \\
\hline \multicolumn{2}{|c|}{ بدرجة كبيرة } & r.ov & $\varepsilon v$ & \multicolumn{2}{|c|}{ بدرجة كبيرة } & r.OV & $\varepsilon r$ & \multicolumn{2}{|l|}{ المتوسط الكلى للاستبانة } \\
\hline
\end{tabular}

$$
\text { يتضح من الجدول (T) النتائج التالية : }
$$

بالنسبة للإِستبانة ككل : بلغ المتوسط الكلى لإستجابات العينة على المعارف

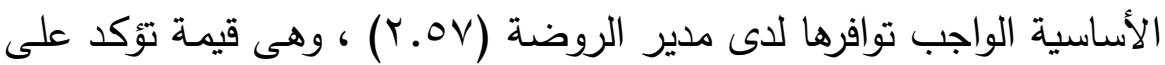




\section{تطوير أداء هدير الروضة فى ضوء المعايير القوهية لرياض الأطفال}

أن جميع المعارف الأساسية التى تضمنتها الإستبانة ذات درجة أهمية كبيرة لتطوير أداء مدير الروضــة في ضـوء مجال القيادة الفعالـة ، فـى حين بلـغ المتوسط الكلى لإستجابات العينة على المهارات المطلوب توافرها لدى مدير الروضـة (Y.OV) ، وهـى قيمـة تؤكد أيضـاً على أن جميع المهارات التىى اشتملت عليها الإستبانة يجب توافرها بدرجة كبيرة لتطوير أداء مدير الروضة في ضوء مجال القيادة الفعالة ، وقد جاء المحور الثالث : ( التزام الأخلاق والقواعد المهنية ) ، فى المرتبة الأولى من حيث درجة الأهمية بين محاور الإستبانة ، مما يؤكد على ضرورة الإهتمام بجميع المعارف والمهارات التى اشتملت عليهـا المعـايير الـواردة بهذا المحور لتطوير الأداء المهنى لمدير الروضة فى ضوء مجال القيادة الفعالة . بالنسـبة للهمسور الأول : ( ترسيخ الثقافة المؤسسية ) بلـن المتوسط العـام لإستجابات العينة على المعارف الاساسية الواجب توافرها : (Y.OY) ، وهى ل قيمـة تؤكـد على أن مؤشـرات المعـارف الأساسـية المتعلقـة بترسـيخ الثقافـة المؤسسية يجب أن تتوافر بدرجة كبيرة لتطوير أداء مدير الروضـة ، كما بلغ المتوسط العام لإستجابات العينـة على المهارات المطلوب توافرها ( •. ب) ، وهى قيمـة تؤكد على أن المهارات المرتبطة بترسيخ الثقافة المؤسسية يجب أن تتـوافر بدرجـة كبيـرة فـى مـدير الروضــة للمسـاهمة فـى نجـاح العمليـة التربويـة برياض الأطفال فى ضوء مجال القيادة الفعالة ، وقد جاء المعيار ( يرصد المشكلات التي قد تؤثر على تحقيق الأهداف الاستراتيجية ويشارك في حلها ) فى المرتبة الأولى بين المعارف الأساسية الواجب توافرها لدى مدير الروضـة بمتوسط حسابى بلغ (·.V.V) وبدرجة أهمية كبيرة ، فى حين 
جاء المعيار ( يستخدم الأسـاليب الحديثة في الإدارة والتخطيط ) فى المرتبة الأولى بين المهارات المطلوب توافرها لدى مدير الروضة بمتوسط حسابى بلغ

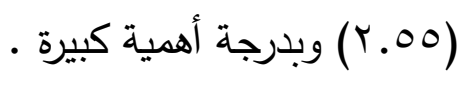

بالنسـبـة للهــور الثــانى : ( دعم التشـاور والمشـاركة ) بلـغ المتوسط العـام لإستجابات العينة على المعارف الاساسية الواجب توافرها : (r.Or) ، وهى قيمـة تؤكـد علـى أن جميـع المعـارف الأساسـية المرتبطـة بـدعم التشـاور والمشاركة يجب أن تتوافر بدرجة كبيرة لتطوير أداء مدير الروضـة ، كما بلغ المتوسط العام لإستجابات العينة على المهارات المطلوب توافرها (ب.01) ، وهى قيمة تؤكد على أن المهارات المرتبطة بدعم التشاور والمشاركة يجب أن تتوافر بدرجـة كبيرة فى مدير الروضـة للمسـاهمة فى نجـاح العمليـة التربويـة برياض الأطفال فى ضوء مجال القيادة الفعالة ، وقد احتل المعيار : ( يوسع فرص مشـاركة المجتمع المدني في دعم مؤسسـات ريـاض الأطفال ) المرتبة الأولى فى درجة الأهمية من حيث المعارف الأساسية أو المهارات المطلوب توافرها لدى مدير الروضـة ، ممـا يؤكد على ضـرورة الأهتمام بهذا المعيار لتطوير أداء مدير الروضة فيما يتعلق بدعم التشاور والمشاركة . بالنسبة للهـور الثالث : ( التزام الأخلاق والقواعد المهنية ) بلغ المتوسط

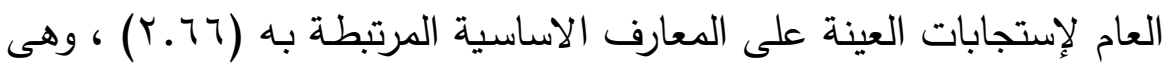
قيمـة تؤكد على أن المعـارف الأساسـية المتعلقـة بـالتزام الأخـاق والقواعيد المهنيـة يجب أن تتوافر بدرجـة كبيرة لتطوير أداء مدير الروضـة ، كما بلـغ

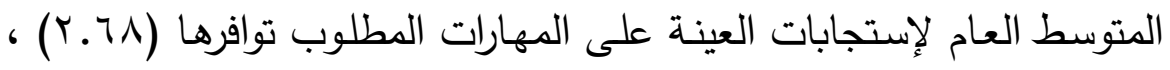
وهى قيمة تؤكد على أن المهارات المرتبطة بالتزام الأخلاق والقواعد المهنية 


\section{تطوير أداء هدير الروضة فى ضوء المعايير القوهية لرياض الأطفال}

يجب أن تتوافر بدرجة كبيرة فى مدير الروضـة للمساهمة فى نجاح العملية التربوية بريـاض الأطفال فى ضوء مجال القيادة الفعالة ، وقد جاء المعيار ( يستتد في قراراته إلى معلومـات موتثـة ودقيقـة ) فى المرتبـة الأولى بين المعارف الواجب توافرها بمتوسط حسابى بلغ (Y.VT) وبدرجة أهمية كبيرة ، فى حين جاء المعيار ( يوظف القائد قدرات ومهارات العاملين لخدمة أهداف العمل) فى المرتبة الأولى بين المهارات المطلوب توافرها لدى مدير الروضـة بمتوسط حسابى (Y.VY) وبدرجة أهمية كبيرة . بالنسبة للهمور الرابع : ( تثجيع المبادأة وإدارة التغيير ) بلـغ المتوسط العام

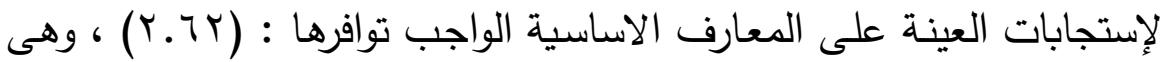
قيمة تؤكد على أن المعارف المتعلقة بتشجيع المبادأة وإدارة التغيير يجب أن تتـوافر بدرجـة كبيـرة لتطـوير أداء مـدير الروضـة ، كمـا بـــن المتوسـط العـام لإستجابات العينـة على المهارات الواجب توافرها ( • ـ Y) ، وهـى قيمة تؤكد على أن المهارات المرتبطـة بتثـيع المبـادأة وإدارة التغيير يجب أن تتـوافر بدرجة كبيرة فى مدير الروضـة للمساهمة فى نجاح العملية التربوية برياض الأطفال فى ضوء مجال القيادة الفعالة ، وقد جاء المعيار ( يستخدم الأساليب الحديثة في تعبئة الأفراد وحفز الجهود ) فى المرتبة الأولى من حيث درجة الأهمية بين المعارف والمهارات المرتبطة بهذا المحور والواجب توافرها لدى مدير الروضـة بمتوسط حسابى (·.V.V) وبدرجة أهمية كبيرة مما يؤكد على ضرورة الأهتمام بهذا المعيار لتطوير أداء مدير الروضـة فيما يتعلق بتشجيع

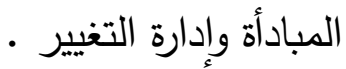




\section{المبلة الملمية لكلية رياض الأطفال س جاهمة بوراسعيد}

\section{(ب) النتائج التفصيلية لإستجابات العينة على الإستبانة}

النتائج المرتبطة بالمهور الأول: ترسيذج الثقافة الموأسسية جدول (๖) النتائج المرتبطة بالمعيار الأول:

يعمل القائد على نشر الوعى بالرؤية المستقبلية لالتعليم فى هصر (ن= ro

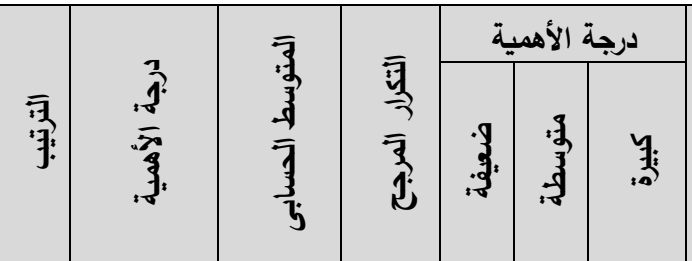

العبارات

يحتاج المدير لإنجاز مؤشرات هذا المعيار مجموعة من المعارف الأساسية، منها:

\begin{tabular}{|c|c|c|c|c|c|c|c|c|}
\hline 1 & كبيرة & Y.71 & IV & $r$ & $\varepsilon$ & 19 & المعايير القومية لرياض الأطفال & 1 \\
\hline r & 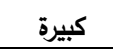 & $r . \leqslant \wedge$ & $\pi$ & r & 9 & $1 \leq$ & قانون الطفل المصري & r \\
\hline$r$ & متوسطة & r.ru & $0 \wedge$ & $r$ & 1 & 11 & وإجلاعتــاء التربوي الهيئـــة القوميـــة لضـــمان الجــودة & $r$ \\
\hline r & 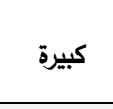 & $Y . £ \wedge$ & Tr & $\bullet$ & $r$ & iv & 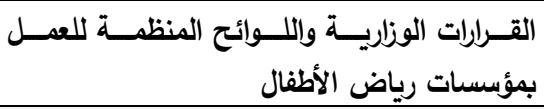 & $\varepsilon$ \\
\hline & 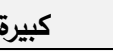 & r. $\leqslant q$ & \multicolumn{6}{|c|}{ المتوسط الحسابي العام لمجموعة المعارف } \\
\hline
\end{tabular}

يحتاج المدير لإنجاز مؤشرات هذا المعيار مجموعة من المهارات المطلوبة، منها:

\begin{tabular}{|c|c|c|c|c|c|c|c|c|}
\hline 1 & كبيرة & r.VY & 71 & $r$ & $r$ & r. & استخدام أساليب الاتصال والتواصل الفعالة. & 0 \\
\hline$r$ & 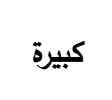 & Y. $\leqslant$. & 7. & $\varepsilon$ & $\checkmark$ & $1 \varepsilon$ & بالروضة. المشاركة في صياغة الرؤيـة والرسـالة الخاصـة & 9 \\
\hline$r$ & متوسطة & r.ru & $\bullet \wedge$ & $\bullet$ & $\checkmark$ & ir & 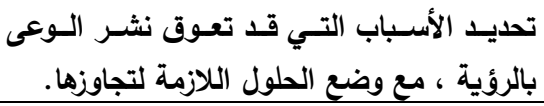 & v \\
\hline$\varepsilon$ & متوسطة & T.Y $\leq$ & 09 & • & 9 & 11 & تلتريئــة المؤسســة لتحقيـق متطلبـات الاعتمــاد & $\wedge$ \\
\hline \multicolumn{2}{|c|}{ كبيرة } & $r . \varepsilon r$ & \multicolumn{6}{|c|}{ المتوسط الحسابى العام لمجموعة المهارات } \\
\hline
\end{tabular}

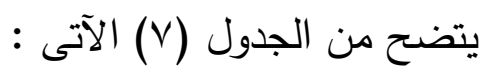

• المتوسط العـام لمؤشرات المعارف الأساسية المرتبطـة بالمعيـار الأول بلـغ :

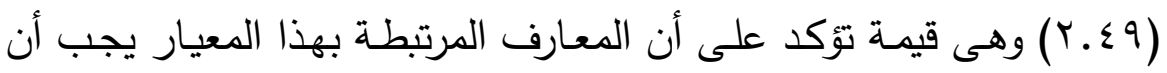

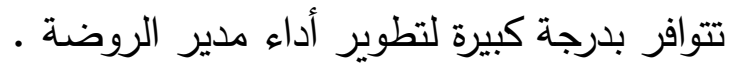

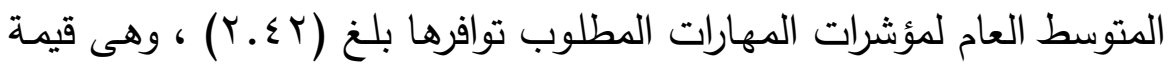

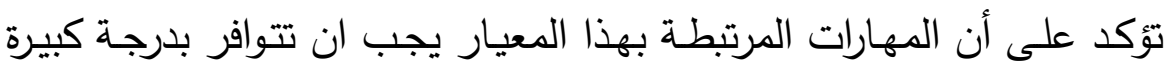
للتأكيد على نجاح العملية التربوية برياض الأطفال . 


\section{تطوير أداء هدير الروضة فى ضوء المعايير القوهية لرياض الأطفال}

\section{جدول (^) النتائج المرتبطة بالمعيار الثانى:}

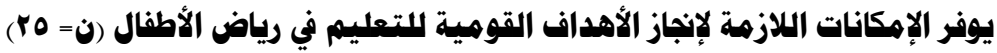

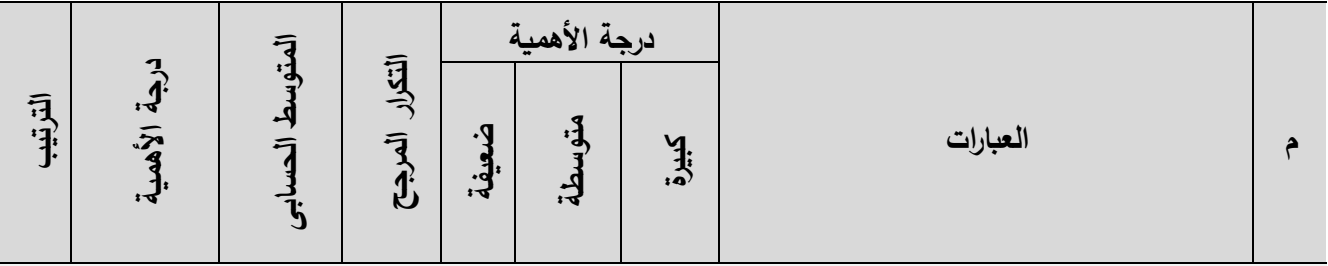

يحتاج المدير لإنجاز مؤشرات هذا المعيار مجموعة من المعارف الأساسية، منها:

\begin{tabular}{|c|c|c|c|c|c|c|c|c|}
\hline 1 & كبيرة & Y.V & 79 & 1 & $\varepsilon$ & $r \cdot$ & لالامك الروضات والموارد البشرية والمادية المتوافرة & 1 \\
\hline r & كبيرة & $Y . \leqslant \wedge$ & Tr & r & 9 & $1 \leq$ & قالمالية. ومتطلبات وإجراءات تطبيق اللامركزيـة & $r$ \\
\hline$r$ & متوسطة & T.YA & ov & $\varepsilon$ & 1. & 11 & التعاصة بهالأهداف القومية وتوفير المعلومـات & $r$ \\
\hline \multicolumn{2}{|c|}{ بلرجة كبيرة } & Y.01 & \multicolumn{6}{|c|}{ المتوسط الحسابى العام لمجموعة المعارف } \\
\hline
\end{tabular}

يحتاج المدير لإنجاز مؤشرات هذا المعيار مجموعة من المهارات المطلوبة، منها:

\begin{tabular}{|c|c|c|c|c|c|c|c|c|}
\hline 1 & 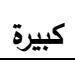 & Y.Tะ & 77 & 1 & $v$ & iv & إدارة الموارد البشرية. & $\varepsilon$ \\
\hline r & 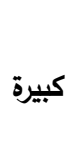 & r.£. & 7. & $\varepsilon$ & $v$ & $1 \leq$ & 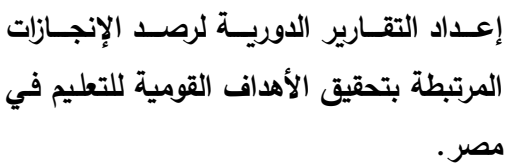 & 0 \\
\hline \multicolumn{2}{|c|}{ بلرجة كبيرة } & r.or & \multicolumn{6}{|c|}{ المتوسط الحسابى العام لمجموعة المهارات } \\
\hline
\end{tabular}

$$
\text { يتبين من الجدول (^) ما يلى : (1) }
$$

المتوسط العـام لمؤشرات المعارف الأساسية المرتبطـة بالمعيار الثانى بلـغ :

(Y.01) وهـى قيمـة تؤكد على أن المعارف المرتبطة بهذا المعيار يجب أن

$$
\text { تتوافر بدرجة كبيرة لتطوير أداء مدير الروضة . }
$$

المتوسط العام لمؤشرات المهارات المطلوب توافرها بلغ (Y.OY) ، وهى قيمة

تؤكد على أن المهارات المرتبطة بهذا المعيار يجب ان تتوافر بدرجة كبيرة للمساهمة فى نجاح العملية التربوية برياض الأطفال . 


\section{الملبة العلمية لكلية رياض الأطفال = جامعة بورسعيد}

جدول (9) النتائج المرتبطة بالمعيار الثالث:

يستخدم الأساليب الحديثة في الإدارة والتخطيط (ن= (ن)

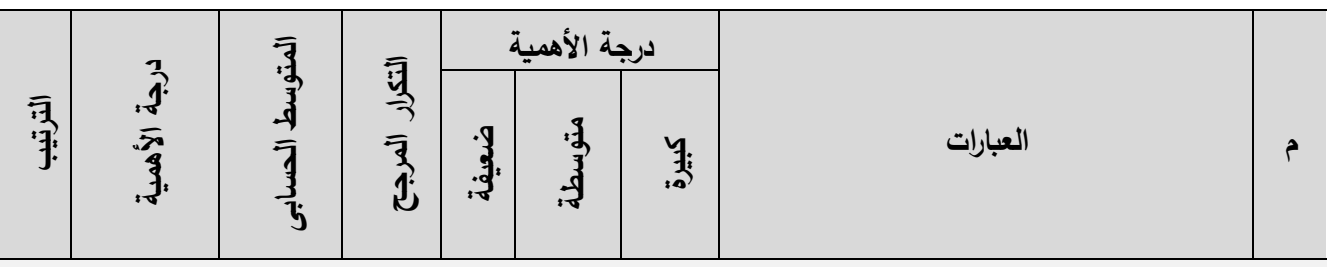

يحتاج المدير لإنجاز مؤشرات هذا المعيار مجموعة من المعارف الأساسية، منها:

\begin{tabular}{|c|c|c|c|c|c|c|c|c|}
\hline 1 & كبيرة & Y.V & 79 & 1 & $\varepsilon$ & $r \cdot$ & بالتقويم. عملــات الإدارة بــــاً بــالتخطيط وإنتهـــاءً & 1 \\
\hline r & كبيرة & r.07 & $7 \varepsilon$ & $r$ & v & 17 & 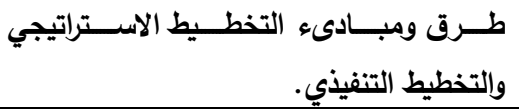 & r \\
\hline$r$ & كبيرة & $Y . \leqslant \wedge$ & it & $\varepsilon$ & 0 & 17 & أسلوب الإدارة بالنتائج. & $r$ \\
\hline$\varepsilon$ & كبيرة & r.ru & 09 & 7 & $\varepsilon$ & 10 & صياغة التقارير الدورية. & $\varepsilon$ \\
\hline \multicolumn{2}{|c|}{ بلرجة كبيرة } & r.O & & & & 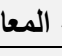 & المتوسط الحسابى العام لمجه & \\
\hline
\end{tabular}

يحتاج المدير لإنجاز مؤشرات هذا المعيار مجموعة من المهارات المطلوبة، منها:

\begin{tabular}{|c|c|c|c|c|c|c|c|c|}
\hline 1 & كبيرة & Y.V & 79 & 1 & $\leqslant$ & r. & توجيه أعمال فرق العمل ومتابعتها. & $\bullet$ \\
\hline$\varepsilon$ & كبيرة & r.m. & $\Delta q$ & 0 & 7 & $1 \varepsilon$ & 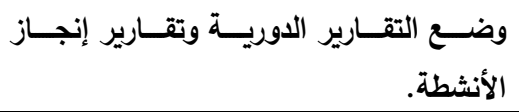 & 7 \\
\hline 1 & كبيرة & Y.V & 79 & 1 & $\varepsilon$ & r. & 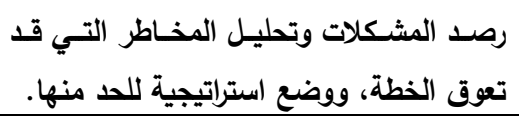 & 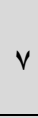 \\
\hline r & كبيرة & $r . £ \wedge$ & Tr & $\varepsilon$ & ○ & 17 & الإدارة. & $\wedge$ \\
\hline$r$ & كبيرة & r. $\varepsilon$. & 7. & 0 & $\bullet$ & 10 & تطبيق البحوث الإجرائية. & 9 \\
\hline \multicolumn{2}{|c|}{ بلرجة كبيرة } & r.०० & \multicolumn{6}{|c|}{ المتوسط الحسابى العام لمجموعة المهارات } \\
\hline
\end{tabular}

المتوسط العام لمؤشرات المعارف الأساسية المرتبطة بالمعيار الثالث بلغن :

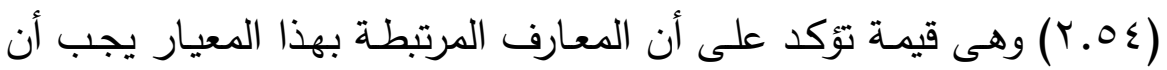

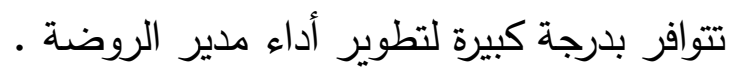

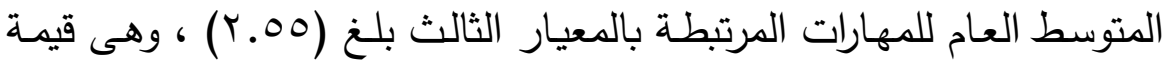
تؤكد على أن المهارات المرتبطة بهذا المعيار يجب ان تتوافر بدرجة كبيرة لضمان نجاح العملية التربوية برياض الأطفال . 


\section{تطوير أداء هدير الروضة فى ضوء المعايير القوهية لرياض الأطفال}

جدول (• النتائج المرتبطة بالمعيار الرابع: يطبق الأساليب الحديثة في المتابعة والتقويم (ن= ro)

\begin{tabular}{|c|c|c|c|c|c|c|}
\hline \multirow[b]{2}{*}{ 蛹 } & \multirow[b]{2}{*}{ ?ר. } & \multirow{2}{*}{$\begin{array}{l}\overline{3} \\
3 \\
\overline{3} \\
\overline{7} \\
3 \\
3 \\
3\end{array}$} & \multirow[b]{2}{*}{$\begin{array}{l}\text { 氞 } \\
\overline{3} \\
\overline{3} \\
\overline{1}\end{array}$} & \multicolumn{3}{|c|}{ درجة الأهمية } \\
\hline & & & & : & శู & 翌 \\
\hline
\end{tabular}

يحتاج المدير لإنجاز مؤشرات هذا المعيار مجموعة من المعارف الأساسية ، منها:

\begin{tabular}{|c|c|c|c|c|c|c|c|c|}
\hline 1 & 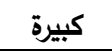 & r.07 & $7 \varepsilon$ & r & $\mathrm{v}$ & 17 & طرق المتابعة والتقويم التي تتبناها الوزارة. & 1 \\
\hline 1 & 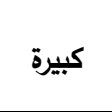 & Y.04 & $7 \leqslant$ & $r$ & 0 & IV & التكوارق بـين أنـواع التقويم المختلفـة، مثل: & r \\
\hline$r$ & متوسطة & r.17 & \& & V & V & 11 & والعلاقة بين المتابعة والتقويم وضمان الجودة & $r$ \\
\hline \multicolumn{2}{|c|}{ بلرجة كبيرة } & $r . \leqslant r$ & \multicolumn{6}{|c|}{ المتوسط الحسابى العام لمجموعة المعارف } \\
\hline
\end{tabular}

يحتاج المدير لإنجاز مؤشرات هذا المعيار مجموعة من المهارات المطلوبة ، منها:

\begin{tabular}{|c|c|c|c|c|c|c|c|c|}
\hline r & كبيرة & r.. & 70 & r & 7 & iv & وضع خطط قياس الأداء وجمع البيانات. & $\varepsilon$ \\
\hline$r$ & 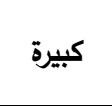 & Y.OY & r & $r$ & 7 & 17 & وضنع التقارير التي تعكس مدى التقدم صوب & 0 \\
\hline$\varepsilon$ & متوسطة & $r . r \leq$ & 09 & $\bullet$ & 9 & 11 & المراجعة المرحلية للخطط على نحو تشاركي. & 7 \\
\hline 1 & 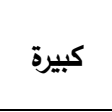 & Y.V & 79 & 1 & $\varepsilon$ & $r$. & متابعــة الأفـراد وتقيـيمهم وقيــاس الكفــاءة & $v$ \\
\hline r & 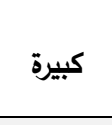 & Ү.५. & 70 & r & 7 & iv & والعدالة. & $\wedge$ \\
\hline \multicolumn{2}{|c|}{ بلرجة كبيرة } & r.० & \multicolumn{6}{|c|}{ المتوسط الحسابى العام لمجموعة المهارات } \\
\hline
\end{tabular}

يظهر من الجدول (• (1) التالى :

•المتوسط العام لمؤشرات المعارف الأساسية المرتبطة بالمعيار الرابع بلـغ :

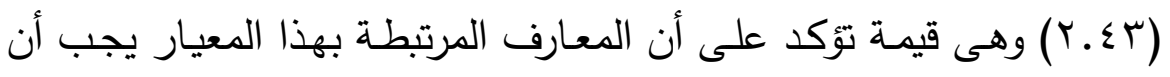

تتوافر بدرجة كبيرة لتطوير أداء مدير الروضة ـ الته

المتوسط العام لمؤشرات المهارات المطلوب توافرها بلغ (؟0.ب) ، وهى قيمة

تؤكد على أن المهارات المرتبطة بهذا المعيار يجب ان تتوافر بدرجة كبيرة للمساهمة فى نجاح العملية التربوية برياض الأطفال . 
جدول (11) النتائج المرتبطة بالمعيار الخامس :

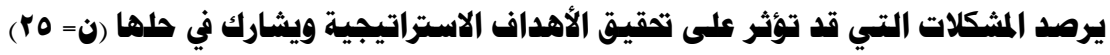

\begin{tabular}{|c|c|c|c|c|c|c|c|c|}
\hline \multirow{2}{*}{ 司: } & \multirow{2}{*}{ 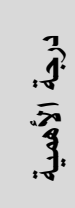 } & \multirow{2}{*}{$\begin{array}{l}\overline{7} \\
\overline{3} \\
\overline{3} \\
\overline{3} \\
3 \\
3\end{array}$} & \multirow{2}{*}{$\begin{array}{l}\text { 氞 } \\
\overline{7} \\
\overline{1}\end{array}$} & \multicolumn{3}{|c|}{ درجة الأهمية } & \multirow[b]{2}{*}{ 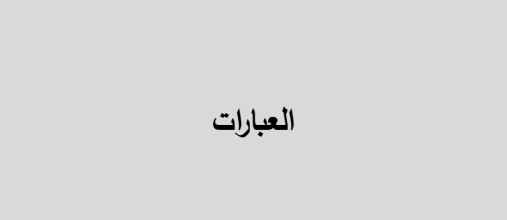 } & \\
\hline & & & & : & $\frac{8}{3}$ & 丵 & & b \\
\hline \multicolumn{9}{|c|}{ يحتاج المدير لإنجاز مؤشرات هذا المعيار مجموعة من المعارف الأساسية ، منها: } \\
\hline 1 & كبيرة & r.V & 79 & 1 & $\varepsilon$ & r. & طرق حل المشكلات. المات & 1 \\
\hline r & 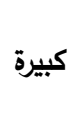 & Y. & 79 & 1 & $\checkmark$ & iv & تمنها. & $r$ \\
\hline \multicolumn{2}{|c|}{ بلرجة كبيرة } & r.V. & \multicolumn{6}{|c|}{ المتوسط الحسابى العام لمجموعة المعارف } \\
\hline
\end{tabular}

يحتاج المدير لإنجاز مؤشرات هذا المعيار مجموعة من المهارات المطلوبة ، منها:

\begin{tabular}{|c|c|c|c|c|c|c|c|c|}
\hline$r$ & كبيرة & Y. $\{\Lambda$ & Tr & $r$ & 9 & $1 \leq$ & وإدارة عمليــة تثـــاركية لتحليـلـل المشــكلات & $r$ \\
\hline 1 & كبيرة & Y.OY & rי & $r$ & 7 & 17 & 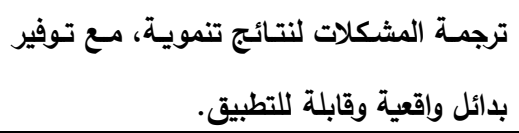 & $\varepsilon$ \\
\hline$r$ & 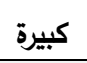 & r.s. & 7. & $\varepsilon$ & 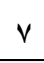 & $1 \varepsilon$ & توثيق ما تم من خبرات خلال حل المشكلات. & 0 \\
\hline \multicolumn{2}{|c|}{ بلرجة كبيرة } & $r . \varepsilon V$ & \multicolumn{6}{|c|}{ المتوسط الحسابى العام لمجموعة المهارات } \\
\hline
\end{tabular}

المتوسط العام لمؤشرات المعارف الأساسية المرتبطة بالمعيار الخامس بلغ :

وهـى قيمة تؤكد على أن المعارف المرتبطة بهذا المعيار يجب أن (Y.V.)

تتوافر بدرجة كبيرة لتطوير أداء مدير الروضة .

المتوسط العام لمؤشرات المهارات المطلوب توافرها بلغ (Y. Y. ) ، وهى قيمة

تؤكد على أن المهارات المرتبطة بهذا المعيار يجب ان تتوافر بدرجة كبيرة

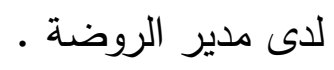




\section{تطوير أداء هدير الروضة فى ضوء المعايير القوهية لرياض الأطفال}

\section{النتائج المرتبطة بلالحمور الثانى: دعم التشاور والمشاركة}

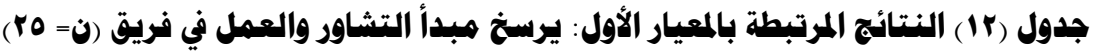

\begin{tabular}{|c|c|c|c|c|c|c|c|c|}
\hline \multirow{2}{*}{ 哥 } & \multirow{2}{*}{ ?.7. } & \multirow{2}{*}{ 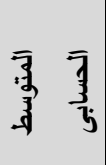 } & \multirow{2}{*}{ 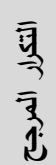 } & \multicolumn{3}{|c|}{ درجة الأهمية } & \multirow[b]{2}{*}{ العبارات } & \\
\hline & & & & 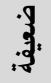 & శู & 絜 & & $?$ \\
\hline
\end{tabular}

يحتاج المدير لإنجاز مؤشرات هذا المعيار مجموعة من المعارف الأساسية ، منها:

\begin{tabular}{|c|c|c|c|c|c|c|c|c|}
\hline r & كبيرة & Y. $\varepsilon \varepsilon$ & 91 & $\varepsilon$ & 7 & 10 & مبادىء وآليات التشاور. & 1 \\
\hline 1 & كبيرة & Y.OY & $7 r$ & $\varepsilon$ & $\varepsilon$ & $1 \mathrm{~V}$ & خصائص فرق العمل وسيكولوجيات الفريق. & $r$ \\
\hline$r$ & كبيرة & Y. $\varepsilon \varepsilon$ & 71 & $\varepsilon$ & 7 & 10 & طرق وآليات بناء فرق العمل. & $r$ \\
\hline \multicolumn{2}{|c|}{ بلدرجة كبيرة } & Y. $\varepsilon V$ & \multicolumn{6}{|c|}{ المتوسط الحسابى العام لمجموعة المعارف } \\
\hline
\end{tabular}

يحتاج المدير لإنجاز مؤشرات هذا المعيار مجموعة من المهارات المطلوبة ، منها:

\begin{tabular}{|c|c|c|c|c|c|c|c|c|}
\hline$r$ & كبيرة & Y.OY & $7 \pi$ & $r$ & 7 & 17 & بنـاء فرق العمـل وتوزيـع الأدوار والمسئوليات على & $\varepsilon$ \\
\hline$r$ & كبيرة & Y.s. & 7. & $\varepsilon$ & V & $1 \leq$ & إدارة آليات للتشاور والحوار داخل مؤسسته. & 0 \\
\hline 1 & كبيرة & Y. . & 77 & 1 & V & $1 \mathrm{~V}$ & حفز وتشجيع العاملين معه على إبداء الرأي والنقد & 7 \\
\hline \multicolumn{2}{|c|}{ بلدرجة كبيرة } & r.Or & \multicolumn{6}{|c|}{ المتوسط الحسابى العام لمجموعة المهارات } \\
\hline
\end{tabular}

$$
\text { يتضح من الجدول (r () الآتى: }
$$

المتوسط العـام لمؤشـرات المعـارف الأساسـية المرتبطـة بالمعيـار الأول بــغن: وهـى قيمة تؤكد على أن المعارف المرتبطة بهذا المعيار يجب أن (Y.

$$
\text { تتوافر بدرجة كبيرة لتطوير أداء مدير الروضة. }
$$

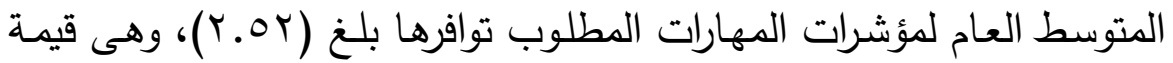

تؤكد على أن المهارات المرتبطة بهذا المعيار يجب ان تتوافر بدرجة كبيرة

لضمان نجاح العملية التربوية برياض الأطفال . 
جدول (rا) النتائج المرتبطة بالمعيار الثانى: يوفر سبل الحصول على المعلوهات وييسر تداولها (ن= ro)

\begin{tabular}{|c|c|c|c|c|c|c|}
\hline \multirow[b]{2}{*}{ 哥! } & \multirow{2}{*}{ 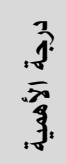 } & \multirow[b]{2}{*}{ 牙示 } & \multirow{2}{*}{ 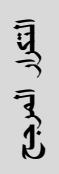 } & \multicolumn{3}{|c|}{ درجة الأهمية } \\
\hline & & & & 疍 & - & 觢 \\
\hline
\end{tabular}

يحتاج المدير لإنجاز مؤشرات هذا المعيار مجموعة من المعارف الأساسية ، منها:

\begin{tabular}{|c|c|c|c|c|c|c|c|c|}
\hline 1 & كبيرة & Y.07 & $7 \varepsilon$ & $r$ & 0 & IV & وإلكترونية). & 1 \\
\hline r & كبيرة & $r . \leqslant \wedge$ & Tr & $r$ & V & 10 & مصادر المعرفة الحكومية الرسمية والمصادر & $r$ \\
\hline$r$ & كبيرة & r.rY & 09 & 0 & 7 & $1 \leq$ & وكيفية نشرها بين المعنيينة وضمانات التـاول الحر للمعلومـات & $r$ \\
\hline
\end{tabular}

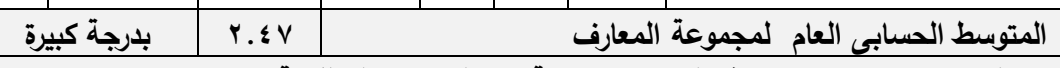
يحتاج المدير لإنجاز مؤشرات هذا المعيار مجموعة من المهارات المطلوبة ، منها:

\begin{tabular}{|c|c|c|c|c|c|c|c|c|}
\hline 1 & 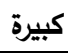 & r.VY & 71 & r & $r$ & r. & بناء وتحديث واستخدام قواعد البيانات. & $\varepsilon$ \\
\hline r & 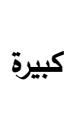 & Y.04 & צ & $\varepsilon$ & $r$ & 11 & تحليـل البيانـات والمعلومـات المتــوافرة لــدى & 0 \\
\hline$r$ & 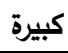 & Y.\&. & 4 & $r$ & 9 & 17 & التوثيق والأرشفة للمعلومات. & 7 \\
\hline \multicolumn{2}{|c|}{ بلرجة كبيرة } & Y.07 & \multicolumn{6}{|c|}{ المتوسط الحسابى العام لمجموعة المهارات } \\
\hline
\end{tabular}

$$
\text { يتبين من الجدول (T I) التالى: }
$$

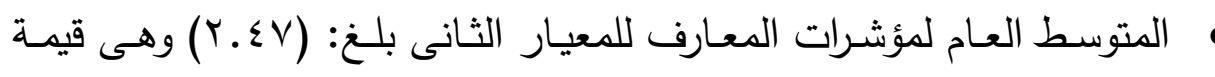
تؤكد على أن المعـارف المرتبطة بهذا المعيار يجب أن تتوافر بدرجة كبيرة

$$
\text { لتطوير أداء مدير الروضة . }
$$

المتوسط العام لمؤشرات المهارات المطلوب توافرها بلغ (ب0. ب) ، وهى قيمة تؤكد على أن المهارات المرتبطة بهذا المعيار يجب ان تتوافر بدرجة كبيرة للمساهمة فى نجاح العملية التربوية برياض الأطفال . 


\section{تطوير أداء هدير الروضة فى ضوء المعايير القوهية لرياض الأطفال}

جدول (§) النتائج المرتبطة بالمعيار الثالث: يشرك العاملين في وضع الخطط واتخاذ القرار (ن= ro)

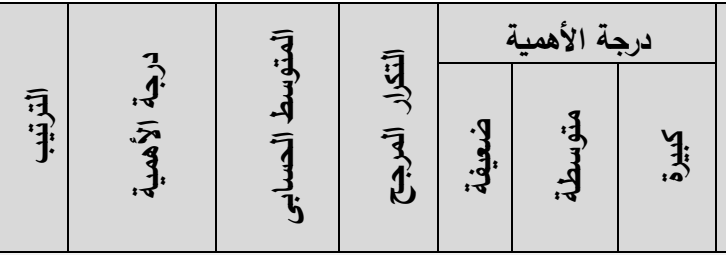

العبارات

يحتاج المدير لإنجاز مؤشرات هذا المعيار مجموعة من المعارف الأساسية ، منها:

\begin{tabular}{|c|c|c|c|c|c|c|c|c|}
\hline 1 & كبيرة & Y..$\leqslant$ & 79 & 1 & $v$ & iv & مبادىء وأساليب المشاركة. & 1 \\
\hline$r$ & كبيرة - & Y.\&. & 7. & $\varepsilon$ & V & $1 \leq$ & طـرق دمــج الأفـراد وتمثيـل المجموعـات فـي & \\
\hline \multicolumn{2}{|c|}{ بدرجة كبيرة } & Y.Or & \multicolumn{6}{|c|}{ المتوسط الحسابى العام لمجموعة المعارف } \\
\hline
\end{tabular}

يحتاج المدير لإنجاز مؤشرات هذا المعيار مجموعة من المهارات المطلوبة ، منها:

\begin{tabular}{|c|c|c|c|c|c|c|c|c|}
\hline 1 & 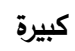 & Y. & 74 & r & • & 11 & صنع القرارات الجماعية. & $r$ \\
\hline 1 & 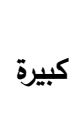 & Y.१ะ & 74 & 1 & $\checkmark$ & iv & توجيه العاملين لفهم وتطبيق عمليات صنع & $\varepsilon$ \\
\hline & 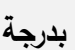 & Y. ร & \multicolumn{6}{|c|}{ المتوسط الحسابى العام لمجموعة المهارات } \\
\hline
\end{tabular}

$$
\text { يظهر من الجدول (ع ا ) ما يلى: }
$$

• المتوسط العام لمؤشـرات المعارف الأساسية المرتبطة بالمعيار الثالث بلـخ : (Y. Y. وهى قيمـة توكد على أن المعارف المرتبطة بهذا المعيار يجب أن

$$
\text { تتوافر بدرجة كبيرة لتطوير أداء مدير الروضة . }
$$

المتوسط العام لمؤشرات المهارات التى تضمنها المعيار الثالث بلغ ( ج. ب) ، وهـى قيمـة تؤكد على أن المهارات المرتبطـة بهذا المعيـار يجـب ان تتوافر بدرجة كبيرة للتأكيد على نجاح العملية التربوية برياض الأطفال . 


\section{الجلة العلمية لكلية رياض الأطفال = جامعة بورسعيد}

جدول (10) النتائج المرتبطة بالمعيار الرابع:

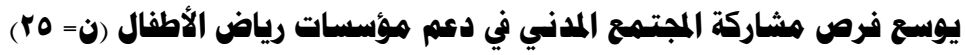

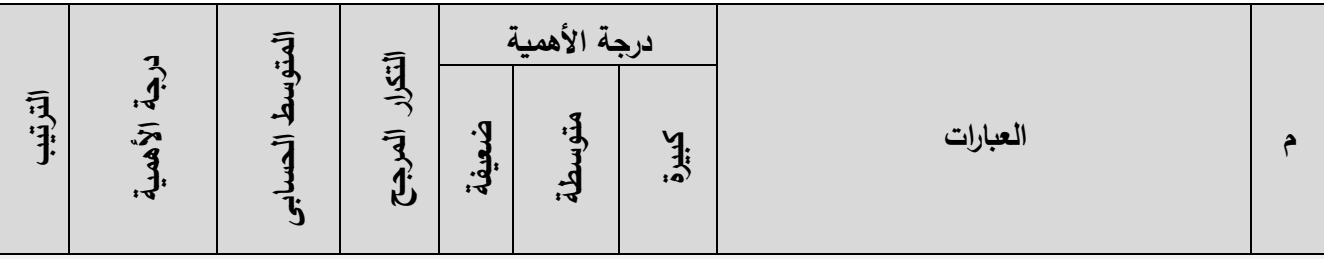

يحتاج المدير لإنجاز مؤشرات هذا المعيار مجموعة من المعارف الأساسية ، منها:

\begin{tabular}{|c|c|c|c|c|c|c|c|c|}
\hline$r$ & كبيرة & $r .71$ & TV & r & $\varepsilon$ & 19 & دليل الروضة والمجتمع. & 1 \\
\hline$r$ & كبيرة & ५. . . & 70 & r & 7 & iv & واليـات الحـوار وبنـاء الشـراكات بـين المجتــع & r \\
\hline 1 & كبيرة & r.Vr & $\checkmark 1$ & 1 & 0 & 19 & وأساليب التعامل مع المؤسسات غير الحكومية & $r$ \\
\hline & بل برجة & r.TV & \multicolumn{6}{|c|}{ المتوسط الحسابى العام لمجموعة المعارف } \\
\hline
\end{tabular}

يحتاج المدير لإنجاز مؤشرات هذا المعيار مجموعة من المهارات المطلوبة ، منها:

\begin{tabular}{|c|c|c|c|c|c|c|c|c|}
\hline r & 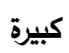 & r.7. & 70 & r & 7 & iv & مهارات الاتصال والتأثير والإقناع. & $\varepsilon$ \\
\hline 1 & 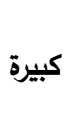 & Y.VY & $\checkmark 1$ & 1 & 0 & 19 & تحفيـز مشــاركة المجتمــع المــنـي لتحقيـق & 0 \\
\hline & & r.79 & \multicolumn{6}{|c|}{ المتوسط الحسابى العام لمجموعة المهارات } \\
\hline
\end{tabular}

$$
\text { يُلاحظ من الجدول (0 10) ما يلى: }
$$

• المتوسط العـام لمؤشرات المعـارف الأساسية المرتبطـة بالمعيار الرابع بلـغ :

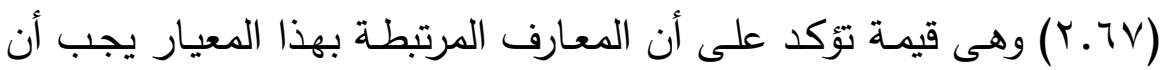

$$
\text { تتوافر بدرجة كبيرة لتطوير أداء مدير الروضة. }
$$

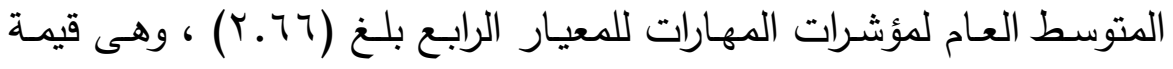

تؤكد على أن المهارات المرتبطة بهذا المعيار يجب ان تتوافر بدرجة كبيرة

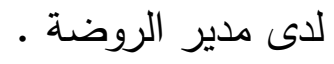




\begin{tabular}{|c|c|c|c|c|c|c|c|c|}
\hline \multicolumn{9}{|c|}{ تطوير أداء هدير الروضة فى ضوء المعايير القوهية لرياض الأطفال } \\
\hline \multicolumn{9}{|c|}{ 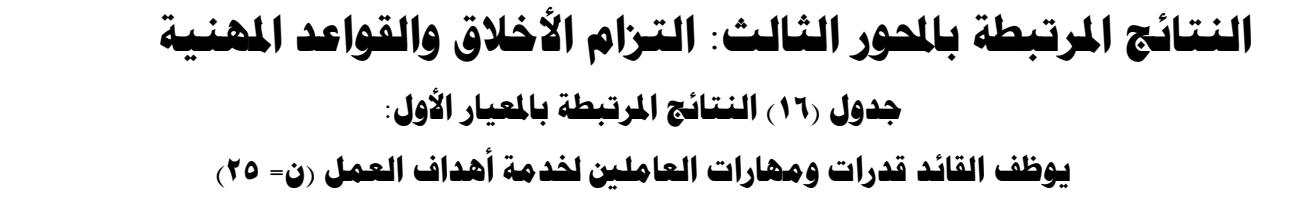 } \\
\hline \multirow[b]{2}{*}{ 䨒! } & \multirow[b]{2}{*}{ 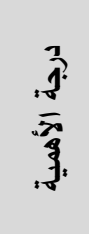 } & \multirow{2}{*}{$\begin{array}{l}\overline{3} \\
\overline{3} \\
\overline{3} \\
\frac{1}{3} \\
\frac{3}{3}\end{array}$} & \multirow[b]{2}{*}{$\begin{array}{l}\text { 氧 } \\
\overline{3} \\
\vdots\end{array}$} & \multicolumn{3}{|c|}{ درجة الأهمية } & \multirow[b]{2}{*}{ 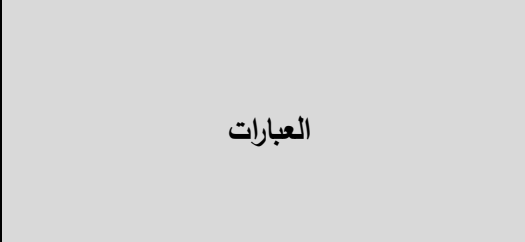 } & \multirow[b]{2}{*}{ s } \\
\hline & & & & S. & 焉 & 㹃 & & \\
\hline \multicolumn{9}{|c|}{ يحتاج المدير لإنجاز مؤشرات هذا المعيار مجموعة من المعارف الأساسية ، منها: } \\
\hline 1 & كبيرة & r.v & 79 & 1 & $\varepsilon$ & r. & |قدرات ومهارات فريق العمل. & 1 \\
\hline r & كبيرة & r. $\leqslant$ & 1 & $\varepsilon$ & 1 & 10 & | طبيعة عمل مجتمعات التعلم المهنية. & r \\
\hline & 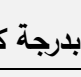 & r.r. & \multicolumn{6}{|c|}{ المتوسط الحسابى العام لمجموعة المعارف } \\
\hline \multicolumn{9}{|c|}{ يحتاج المدير لإنجاز مؤشرات هذا المعيار مجموعة من المهارات المطلوبة ، منها: } \\
\hline r & كبيرة & r.V4 & 79 & 1 & $\varepsilon$ & $r \cdot$ & | تلعزيع الأدوار والمسئوليات بين أفراد فريق & $r$ \\
\hline$r$ & كبيرة & r.04 & $1 \leq$ & r & v & 14 & | إدارة جلسات النقاش. & $\varepsilon$ \\
\hline 1 & كبيرة & r.^६ & $v_{1}$ & . & $\varepsilon$ & $r$ & | التواصل مع العاملين. & 。 \\
\hline & بلبرجة كا & r.vr & \multicolumn{6}{|c|}{ المتوسط الحسابى العام لمجموعة المهارات } \\
\hline \multicolumn{9}{|c|}{ 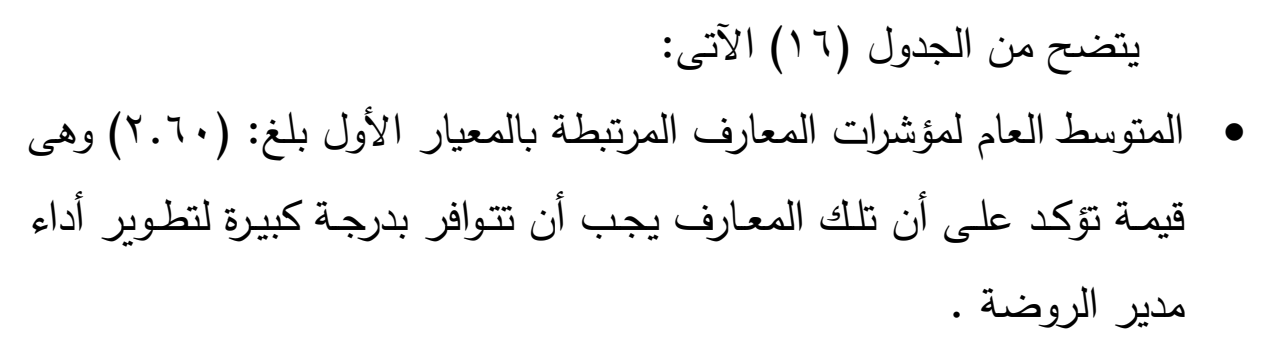 } \\
\hline \multicolumn{9}{|c|}{ 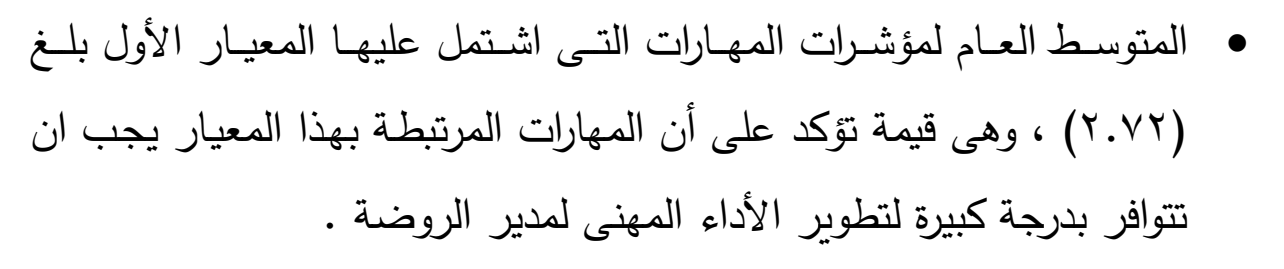 } \\
\hline \multicolumn{8}{|r|}{ 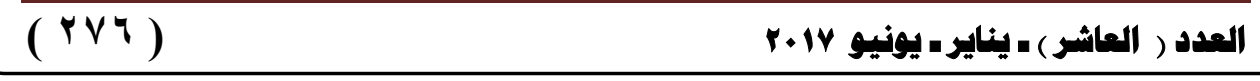 } & \\
\hline
\end{tabular}




\section{الملة العلمية لكلية رياض الأطفال = جامعة بورسعيد}

جدول (IV) النتائج المرتبطة بالمعيار الثانى: يطبق أسلوب العمل في فريق العمل والقيادة الجماعية (ن= YO)

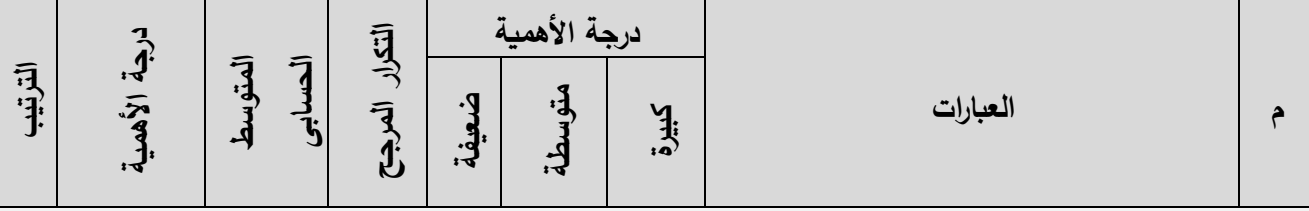

يحتاج المدير لإنجاز مؤشرات هذا المعيار مجموعة من المعارف الأساسية ، منها:

\begin{tabular}{|c|c|c|c|c|c|c|c|c|}
\hline 1 & 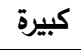 & T.7 & 79 & 1 & $v$ & iv & مبادىء العمل في فريق وطرق بنائه. & 1 \\
\hline r & 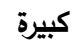 & Y.07 & $7 \varepsilon$ & r & $v$ & 17 & خصائص الذكاء الوجداني. & r \\
\hline \multicolumn{2}{|c|}{ بلرجة كبيرة } & r.7. & \multicolumn{6}{|c|}{ المتوسط الحسابى العام لمجموعة المعارف } \\
\hline
\end{tabular}

يحتاج المدير لإنجاز مؤشرات هذا المعيار مجموعة من المهارات المطلوبة ، منها:

\begin{tabular}{|c|c|c|c|c|c|c|c|c|}
\hline 1 & 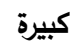 & Y.V & 79 & 1 & $\varepsilon$ & r. & قيادة فرق العمل. & $r$ \\
\hline r & كبيرة & ५.५. & 70 & r & 9 & iv & تفويض السلطة والمسئوليات. & $\varepsilon$ \\
\hline \multicolumn{2}{|c|}{ بلرجة كبيرة } & ५. ^ & \multicolumn{6}{|c|}{ المتوسط الحسابى العام لمجموعة المهارات } \\
\hline
\end{tabular}

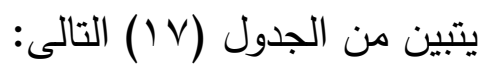

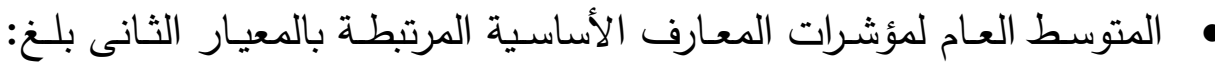

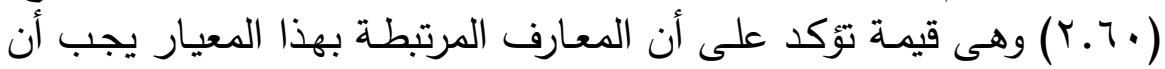

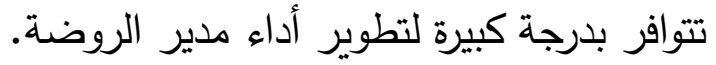

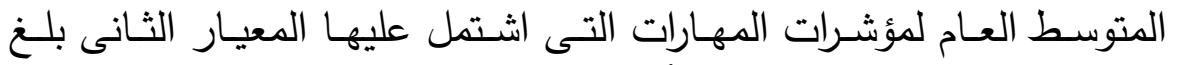

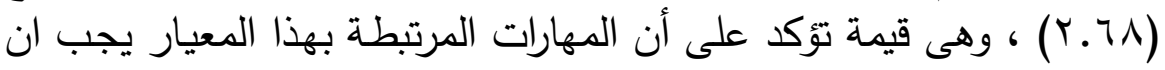

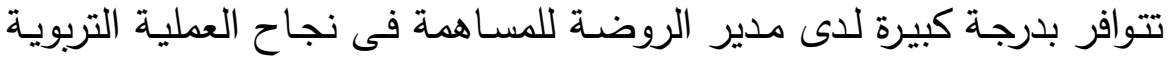

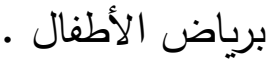
جدول (1A) النتائج المرتبطة بالمعيار الثالث: يستند في قراراته إلى هعلوهات هوثقة ودقيقة (ن= ب0)

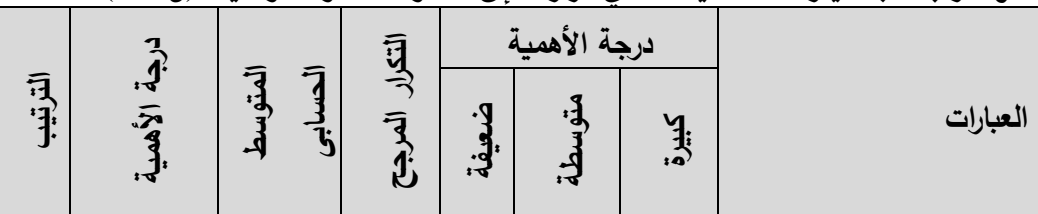

\begin{tabular}{|c|c|c|c|c|c|c|c|c|}
\hline 1 & كبيرة & Y.A $\varepsilon$ & vi & 1 & r & rr & القوانين واللوائح والقرارات الإدارية. & 1 \\
\hline r & كبيرة & r.५ & iv & r & $\varepsilon$ & 19 & أساليب جمع وتحليل البيانات. & r \\
\hline & كبير & Y.V & \multicolumn{6}{|c|}{ المتوسط الحسابى العام لمجموعة المعارف } \\
\hline \multicolumn{9}{|c|}{ يحتاج المدير لإنجاز مؤشرات هذا المعيار مجموعة من المهارات المطلوبة ، منها: } \\
\hline r & 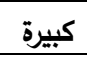 & r.Y. & 10 & r & 7 & iv & استقراء الوثائق والتقارير وملخصاتها التنفيذية. & $r$ \\
\hline 1 & 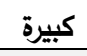 & Y.VY & 79 & 1 & $\varepsilon$ & r. & جمع وتحليل البيانات. & $\varepsilon$ \\
\hline & 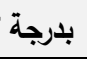 & ५.५^ & \multicolumn{6}{|c|}{ المتوسط الحسابى العام لمجموعة المهارات } \\
\hline
\end{tabular}

يحتاج المدير لإنجاز مؤشرات هذا المعيار مجموعة من المعارف الأساسية ، منها: 


\section{تطوير أداء هدير الروضة فى ضوء المعايير القوهية لرياض الأطفال}

$$
\text { يظهر من الجدول (1/1) ما يلى : }
$$

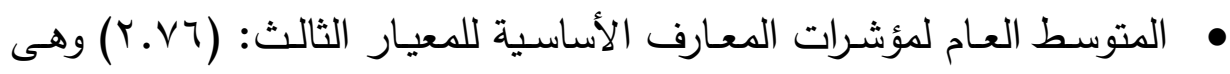
قيمـة تؤكد على أن المعارف المرتبطـة بهذا المعيار يجب أن تتوافر بدرجـة

$$
\text { كبيرة لتطوير أداء مدير الروضة . }
$$

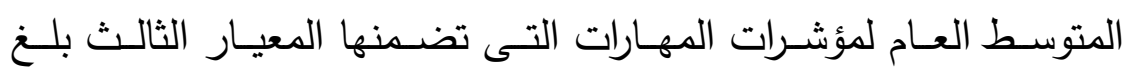

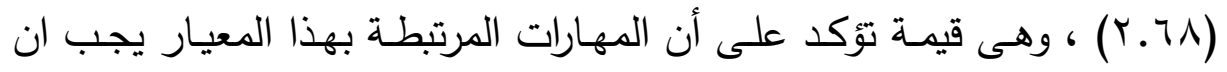
تتوافر بدرجة كبيرة للمساهمة فى نجاح العملية التربوية برياض الأطفال .

\begin{tabular}{|c|c|c|c|c|c|c|c|c|}
\hline \multirow[b]{2}{*}{ 雪! } & \multirow{2}{*}{ ?.7. } & \multirow[b]{2}{*}{$\begin{array}{ll}\overline{3} & \overline{7} \\
3 & 3 \\
3 & 3\end{array}$} & \multirow{2}{*}{ 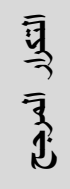 } & \multicolumn{3}{|c|}{ درجة الأهمية } & \multirow[b]{2}{*}{ العبارات } & \\
\hline & & & & 䙢 & 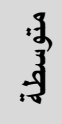 & 啰 & & p \\
\hline
\end{tabular}

جدول (19) النتائج المرتبطة بالمعيار الرابع: يبدى التقدير والاحترام للعاهلين هعه (ن= ب0)

\begin{tabular}{|c|c|c|c|c|c|c|c|c|}
\hline 1 & كبيرة & Y.VY & 79 & - & 7 & 19 & اللوائح الخاصة بتحفيز العاملين. & 1 \\
\hline r & كبيرة & Y.07 & $7 \leq$ & r & v & 17 & خصائص ومهارات وقدرات وإنجازات العاملين. & r \\
\hline \multicolumn{2}{|c|}{ بلرجة كبيرة } & Y.77 & \multicolumn{6}{|c|}{ المتوسط الحسابى العام لمجموعة المعارف } \\
\hline
\end{tabular}

يحتاج المدير لإنجاز مؤشرات هذا المعيار مجموعة من المعارف الأساسية ، منها:

\begin{tabular}{|c|c|c|c|c|c|c|c|c|}
\hline r & 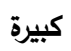 & $r . \varepsilon \Lambda$ & yr & r & 9 & $1 \leq$ & سبل تعزيز الأداءات الجيدة والاحتفاء بها. & $r$ \\
\hline 1 & كبيرة & Y.VY & 79 & 1 & $\varepsilon$ & $r \cdot$ & دعم روح الزمالة بين العاملين. & $\varepsilon$ \\
\hline \multicolumn{2}{|c|}{ بلرجة كبيرة } & r.7r & \multicolumn{6}{|c|}{ المتوسط الحسابى العام لمجموعة المهارات } \\
\hline
\end{tabular}

يحتاج المدير لإنجاز مؤشرات هذا المعيار مجموعة من المهارات المطلوبة ، منها:

$$
\text { يتضح من الجدول (9 (1) الآتى: }
$$

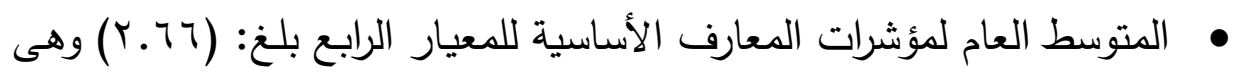

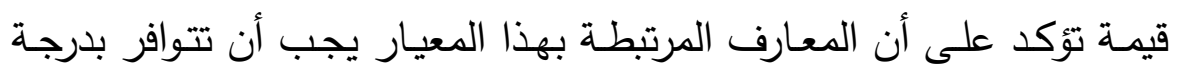

$$
\text { كبيرة لتطوير أداء مدير الروضة . }
$$

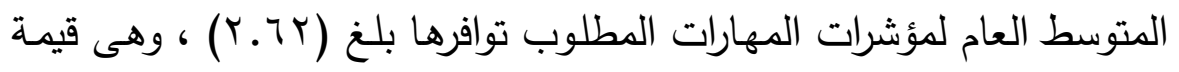
تؤكد على أن المهارات المرتبطة بهذا المعيار يجب ان تتوافر بدرجة كبيرة

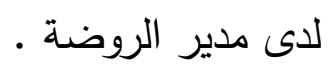


النتائج المرتبطة بالمهور الرابع: تشبيع المبادأة وإدارة التغيير

جدول (•r) النتائج المرتبطة بالمعيار الأول: يشجع القائد على التجريب والتجديد في بيئة العمل (ن= (ro)

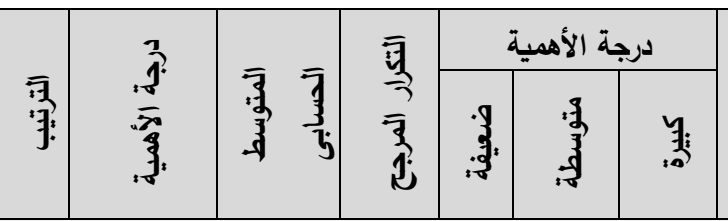

$$
\text { العبارات }
$$

يحتاج المدير لإنجاز مؤشرات هذا المعيار مجموعة من المعارف الأساسية ، منها:

\begin{tabular}{|c|c|c|c|c|c|c|c|c|}
\hline r & 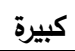 & r. $\leqslant \varepsilon$ & 11 & $\varepsilon$ & 7 & 10 & مبادىء التغيير المؤسسي. & 1 \\
\hline 1 & 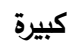 & r.7 & 79 & 1 & $v$ & iv & طرق تحفيز أصحاب الأفكار المبدعة. & $r$ \\
\hline & كبي & r.० & \multicolumn{6}{|c|}{ المتوسط الحسابي العام لمجموعة المعارف } \\
\hline
\end{tabular}

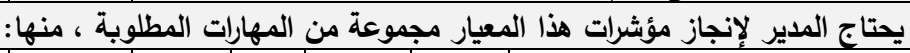

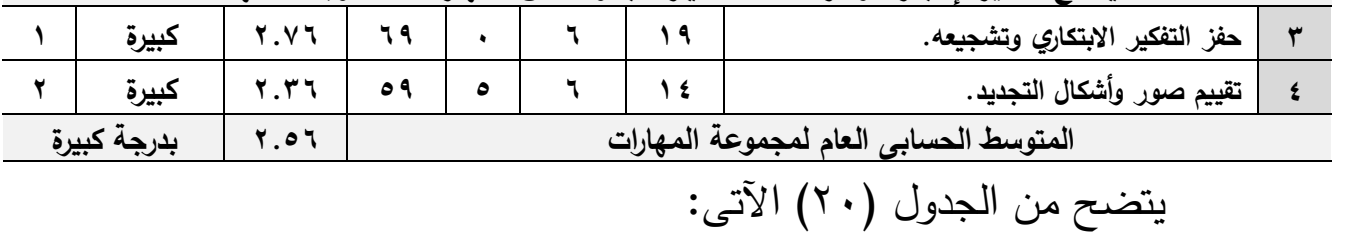

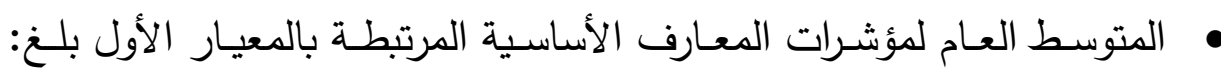

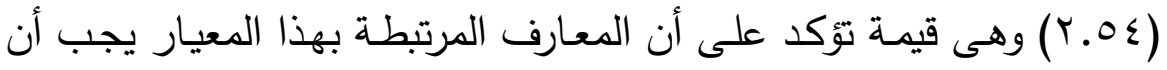

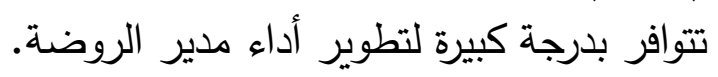

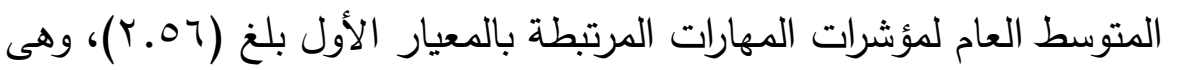

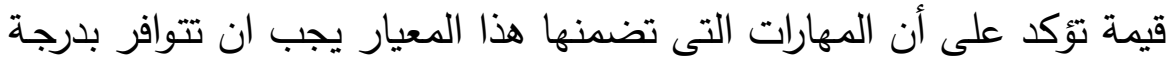

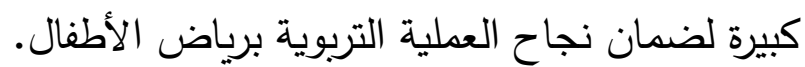

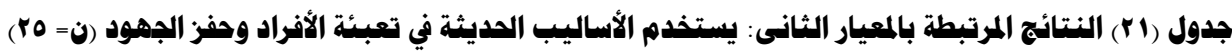

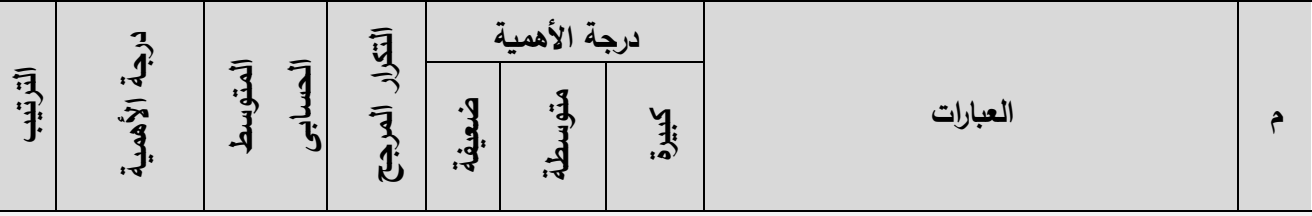

يحتاج المدير لإنجاز مؤشرات هذا المعيار مجموعة من المعارف الأساسية ، منها:

\begin{tabular}{|c|c|c|c|c|c|c|c|c|}
\hline r & كبيرة & Y.५ & iv & 1 & 7 & 11 & مبادىء وطرق تعبئة الموارد البشرية. & 1 \\
\hline 1 & كبيرة & Y.V५ & 79 & . & 9 & 19 & وأنــواعة الحــــوافز (داخليــة وخارجيــة - عينــــة & r \\
\hline & 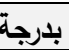 & r.v. & \multicolumn{6}{|c|}{ المتوسط الحسابي العام لمجموعة المعارف } \\
\hline \multicolumn{9}{|c|}{ يحتاج المدير لإنجاز مؤشرات هذا المعيار مجموعة من المهارات المطلوبة ، منها: } \\
\hline r & 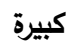 & r.7 & 79 & r & • & 11 & ابتكار وسائل متعددة وغير تقليدية لتعبئة الجهود. & $r$ \\
\hline 1 & كبيرة & r.V५ & 79 & . & 7 & 19 & حفز العاملين لبذل أقصى جها لتحقيق الأهداف & $\varepsilon$ \\
\hline & & r.v. & \multicolumn{6}{|c|}{ المتوسط الحسابى العام لمجموعة المهارات } \\
\hline
\end{tabular}




\section{تطوير أداء هدير الروضة فى ضوء المعايير القوهية لرياض الأطفال}

$$
\text { يتبين من الجدول (إY) الآتى : }
$$

المتوسط العام لمؤشرات المعارف الأساسية المرتبطـة بالمعيار الثانى بلـغ : وهـى قيمة تؤكد على أن المعارف المرتبطة بهذا المعيار يجب أن (Y.V.)

$$
\text { تتوافر بدرجة كبيرة لتطوير أداء مدير الروضة . }
$$

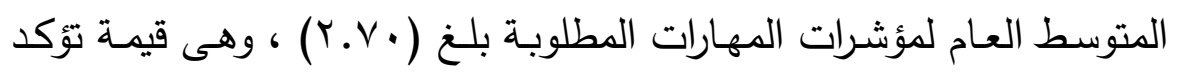
على أن المهارات ذات الصـلة بهذا المعيـار يجب ان تتوافر بدرجـة كبيـرة للتأكيد على نجاح العملية التربوية برياض الأطفال . جدول (rr) النتائج المرتبطة بالمعيار الثالث: يحرص على تفويض السلطات وخلق كوادر جديدة (ن= ro )

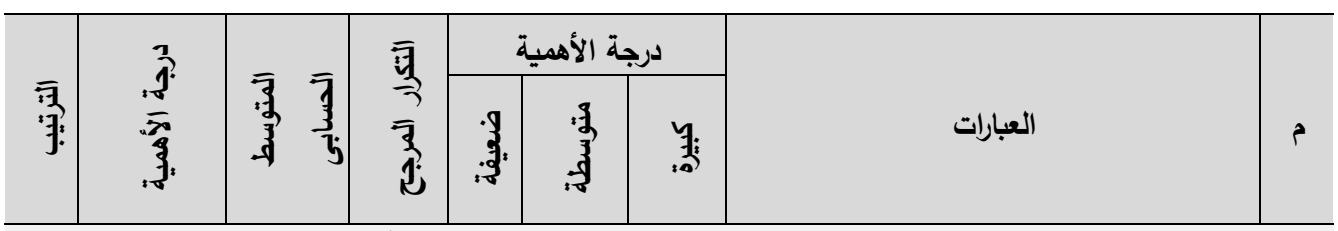

\begin{tabular}{|c|c|c|c|c|c|c|c|c|}
\hline 1 & 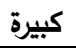 & Y..$\leq$ & 79 & 1 & V & iv & مبادىء وطرق تفويض ونقل وتولي السلطة. & 1 \\
\hline r & 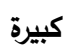 & r.० & $7 \leq$ & $r$ & $\bullet$ & iv & مبادىء وطرق اكتثاف المبدعين. & $r$ \\
\hline \multicolumn{2}{|c|}{ بلرجة كبيرة } & Y.7. & \multicolumn{6}{|c|}{ المتوسط الحسابى العام لمجموعة المعارف } \\
\hline
\end{tabular}

يحتاج المدير لإنجاز مؤشرات هذا المعيار مجموعة من المعارف الأساسية ، منها:

\begin{tabular}{|c|c|c|c|c|c|c|c|c|}
\hline$r$ & كبيرة - كبرة & r.०r & 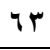 & $r$ & 7 & 17 & مهارة تفويض السلطات. & $r$ \\
\hline 1 & كبيرة - كبرة & Y.0 & $7 \varepsilon$ & $r$ & 0 & IV & اكتشاف وجذب المبدعين ومساندتهم. & $\varepsilon$ \\
\hline \multicolumn{2}{|c|}{ بلدرجة كبيرة } & Y.० & \multicolumn{6}{|c|}{ المتوسط الحسابى العام لمجموعة المهارات } \\
\hline
\end{tabular}

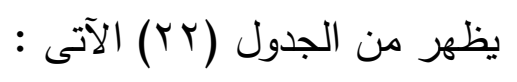

• المتوسط العام لمؤشرات المعارف الأساسية المرتبطة بالمعيار الثالث بلغ :

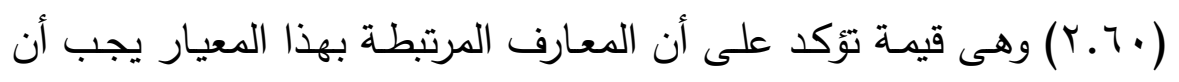
تتوافر بدرجة كبيرة لتطوير أداء مدير الروضة .

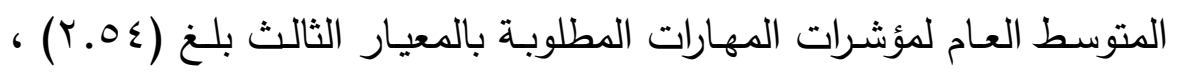
وهى قيمة تؤكد على أن المهارات التى اشتمل عليها المعيار الثالث يجب ان تتوافر بدرجة كبيرة للمساهمة فى نجاح العملية التربوية برياض الأطفال . 


\section{الجلة العلمية لكلية رياض الأطفال = جامعة بورسعيد}

جدول (rr) النتائج المرتبطة بالمعيار الرابع:

يتقبل الأنكار والآراء ويستثمرها لتطوير العمل بمؤسسات رياض الأطفال (ن= ro)

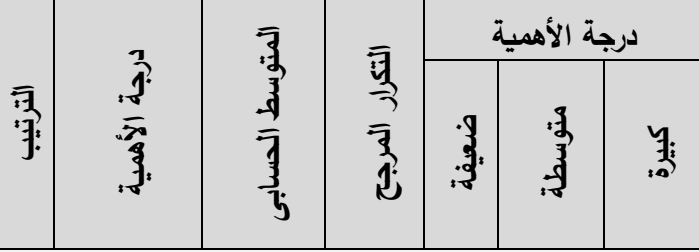

العبارات

يحتاج المدير لإنجاز مؤشرات هذا المعيار مجموعة من المعارف الأساسية ، منها:

\begin{tabular}{|c|c|c|c|c|c|c|c|c|}
\hline 1 & كبيرة & r. & 79 & 1 & $v$ & iv & أنماط التفكير . & 1 \\
\hline$r$ & 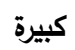 & r.7. & 90 & 1 & $\wedge$ & 17 & طرق النقد البناء. & r \\
\hline \multicolumn{2}{|c|}{ بلرجة كبيرة } & r.tr & \multicolumn{6}{|c|}{ المتوسط الحسابي العام لمجموعة المعارف } \\
\hline
\end{tabular}

يحتاج المدير لإنجاز مؤشرات هذا المعيار مجموعة من المهارات المطلوبة ، منها:

\begin{tabular}{|c|c|c|c|c|c|c|c|c|}
\hline 1 & 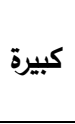 & Y.71 & IV & r & $\varepsilon$ & 19 & خارج الصنفير الناقد والإبـاعي ومـا يسـى التفكير & $r$ \\
\hline$r$ & 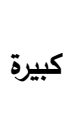 & r.०५ & $7 \varepsilon$ & $r$ & 0 & iv & واليــات تثــيع واســتغلال الأفكـار البنــاءة & $\varepsilon$ \\
\hline$r$ & 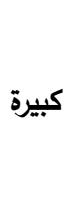 & r.०५ & $7 \varepsilon$ & $r$ & 0 & iv & لهذيل تحديات التطوير المستقبلي للمؤسسـة & • \\
\hline & بلرج & r.१. & \multicolumn{6}{|c|}{ المتوسط الحسابى العام لمجموعة المهارات } \\
\hline
\end{tabular}

المتوسط العام لمؤشرات المعارف الأساسية المرتبطة بالمعيار الرابع بلـغ :

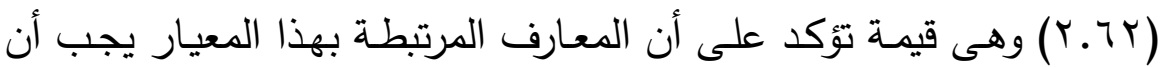

$$
\text { تتوافر بدرجة كبيرة لتطوير أداء مدير الروضة . }
$$

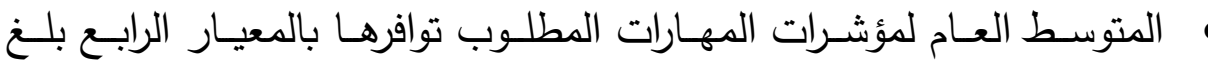

( • (Y. ) ، وهى قيمة تؤكد على أن المهارات التى اشتمل عليها المعيار الرابع

يجب ان تـوافر بدرجـة كبيـرة للتأكيد على نجـاح العمليـة التربويـة بريـاض

الأطفال 


\section{تطوير أداء هدير الروضة فى ضوء المعايير القوهية لرياض الأطفال}

\section{توصيات الدراسة :}

وأخيراً ، فـان رعايـة أطفالنـا في هذه المرحلـة العمريـة المبكرة مسـألة دقيقة

لهـا أهميتهـا ، تتطلـب مـن جهات عديـدة بـذل الجهـود لنجـاح العمليـة التربويـة بريـاض الأطفال ، وعلى الرغم من أهمية اكتسـاب مديري الروضـات المعارف والمهارات سابقة الذكر ، والعمل على وضعها موضـع التطبيق الفعلي بمؤسسات رياض الأطفال ، إلا أنه يلزم على وزارة التربية والتعليم وتتظيماتها المتعددة القيام :بما يلي

رسـم السياسـات والخطط الاسـتراتيجية الواقعيـة بمـا يوجـه الامكانـات الماديـة والبشرية ، ويطور نظم العمل والإدارة مركزيـاً ومحلياً نحو توفير كل مـا من شأنه أن يخلق مناخـاً تربوياً مواتياً للتعلم ، في مؤسسات جيدة الإدارة تخدم الطفل وتضسه في بؤرة اهتمامها، وهو ما يضنمن في النهاية الحصول على نواتج تعلم عالية الجودة . تحـديث الهيكـل الإداري لمرحلـة ريـاض الأطفـال ، لـدعم اسـتقلالية إدارات ريـاض الأطفـال على جميـع المسـتويات ( الـوزارة ، المـديريات ، الإدارات ، الروضات ) ، وفصل ميزانياتها عن ميزانية التعليم الابتدائي • دعـم تطبيـق اللامركزيـة وزيـادة صـلاحيات مـديري الروضـات مسن النـواحي الإدارية، وتمكين المديرين من صناعة القرار وتوسيع المشاركة المجتمعية . بناء حقيبة تدريبية متكاملة من خلال خبراء متخصصون ، تعمل على تحويل تلك الاحتياجات المعرفية والمهارية إلى واقع عملي ، مـع مراعاة التفاوت في مؤهلات وخبرات السادة مديري مؤسسات رياض الأطفال . 
توفير فرص متعددة لمديري مؤسسات رياض الأطفال ، للحصول على تلك المعـارف الهامـة ، وكذا اتقـان المهارات اللازمـة لتطبيق مؤشـرات ومعـايير

مجال القيادة الفعالة ، ومن بين هذه الفرص : - - الدورات التدريبية المتخصصة. - - البعثات للدول المتقدمة في هذا المجال. - تيسـير الحصـول على دراسـات عليـا بكليات ريـاض الأطفـال أو أقسام رياض الأطفال وتربية الطفل بكليات التربية.

$$
\begin{aligned}
& \text { - - برامج إعداد القادة. } \\
& \text { - ـ ورش العمل } \\
& \text { - - الندوات والمؤتمرات. } \\
& \text { - - المشروعات. } \\
& \text { - الزيارات الميدانية. }
\end{aligned}
$$

- إجراء البحوث والدراسات المتخصصة ... وغيرها.

رفع الـوعي بـين السـادة مـديري مؤسسـات ريـاض الأطفـال - خاصـة غيـر المتخصصين - بأهمية هذه المرحلة في حياة الطفل، ومعرفة خصائص نمو الطفل، وسبل دعمها لتحقق أهدافها المرجوة منها. الإعداد التربوي المميز لكادر متخصص من معلمات رياض الأطفال، ليحلوا محل السادة المديرين غير المتخصصين خلال خطة متوسطة المدى (خلال مدة لا تزيد على خمس سنوات)، بحيث يدير مؤسسات رياض الأطفال في مصر نخبة من المديرين المتخصصين وفق معايير الجودة. 


\section{تطوير أداء هدير الروضة فى ضوء المعايير القوهية لرياض الأطفال}

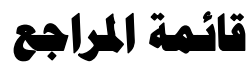

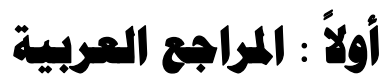

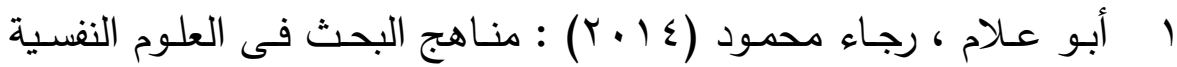

والتربوية ، الطبعة التاسعة ، دار النشر للجامعات ، القاهرة .

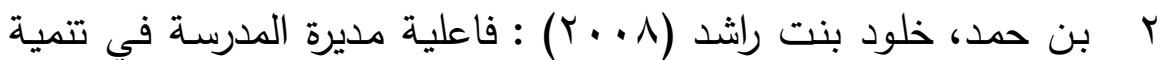
مهارة الإدارة الصفية لدى معلمات رياض الأطفال بمدينة الرياض ، رسالة ماجستير غير منشورة ، كلية التربية ، جامعة الملك سعود .

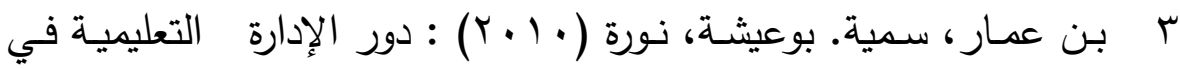
تحقيق جودة التعليم الجامعي " مـع تقديم نموذج مقترح " ، مجلة العلوم الإنسانية والإجتماعية ، جامعة محمد الخامس ، العدد (Or)

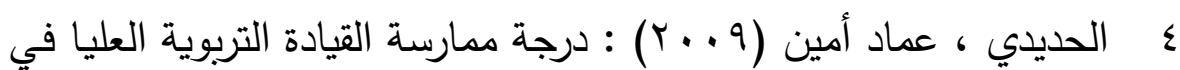
وزارة التربيـة والتعليم العـالي الفلسطينية لدورها الإداري في ضـوء الفكر الإداري الحـديث. ، رسـالة ماجسـتير غيـر منشـورة ، عمــادة الدراسـات العليا ، الجامعة الإسلامية بغزة .

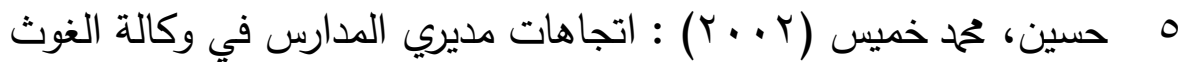
الدولية في الأردن نحو برنامج التربية الرياضية المدرسية ، مجلة جامعة النجاح للأبحاث ، العلوم الإنسـانية ، الأردن ، المجلد (7 ( ) ، العدد - الثاني

T لدورها الإداري في وزارة التربية والتعليم العالي الفلسطينية ، مجلة جامعة دمشق ، المجلد (ع r) ، العدد الأول

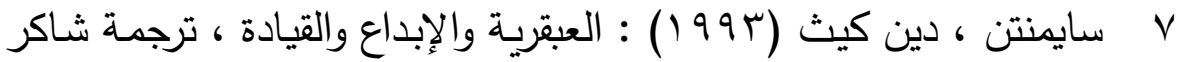


عبدالحميد ، الكويت ، عالم المعرفة

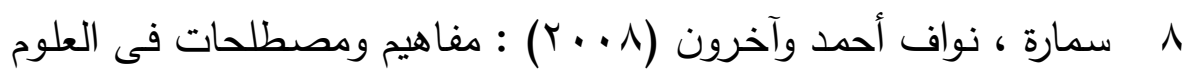
التربوية ، دار المسيرة ، عمان

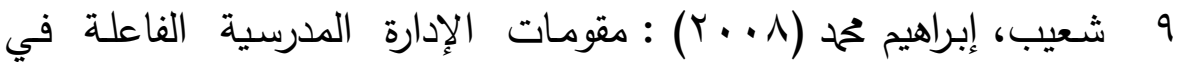
المدارس الحكومية بمحافظات غزة من وجهة نظر المديرين وسبل الارتقاء بها ، رسـالة ماجستير غير منشورة ، عمـادة الدراسـات العليا ، الجامعـة

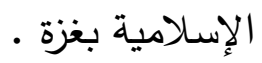

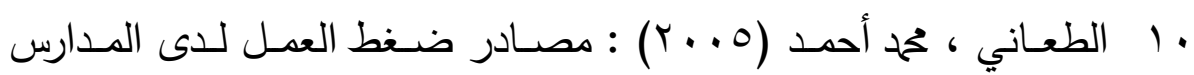
الحكومية في محافظة الكرك من وجهة نظرهم ، مجلة جامعـة دمشق ، كلية العلوم التربوية ، جامعة مؤتة ، المجلد (ب) ، العدد الثاني

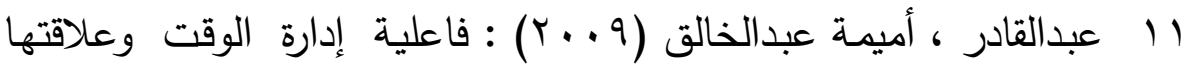
بالأنماط القيادية لدى مديري المدارس الثانوية بمحافظات غزة من وجهة نظرهم ، رسالة ماجستير غير منشورة ، عمادة الدراسات العليا ، الجامعة

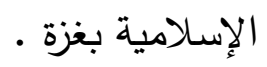

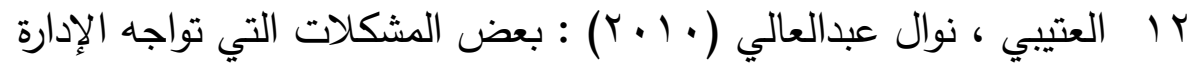
المدرسية لرياض الأطفال الحكومية بمدينة الرياض ، رسالة ماجستير غير منشـورة ، كليـة العلـوم الاجتماعيـة ، جامعـة الإمـام تحمد بـن سـود الاسلامية .

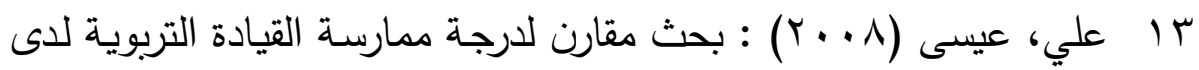
مديري مـدارس التعليم الأساسـي في مدينتي دمشـق وحمص وعلاقتها ببعض المتغيرات ، مجلة جامعة دمشق ، كلية التربية ، المجلد (ع ب) ،

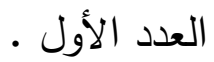




\section{تطوير أداء هدير الروضة فى ضوء المعايير القوهية لرياض الأطفال}

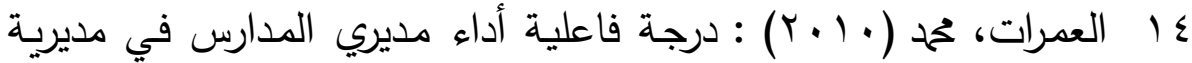
تربيـة البتراء مـن وجهـة نظـر المعلمين فيهـا ، المجلـة الأردنيـة للعلـوم التربويـة ، كليـة العلوم التربويـة ، جامعـة تافيلا ، الأردن ، المجلد (6) ، (4) العدد (4)

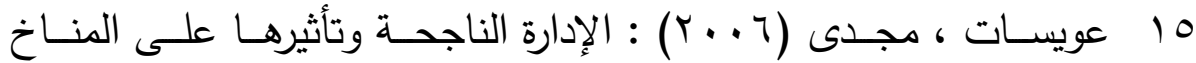
المدرسي ( بحث ميداني بشرقي القدس ) ، مجلة جامعة النجاح للأبحاث، العلوم الإنسانية ، الأردن ، المجلد (ع ب) ، العدد الثاني

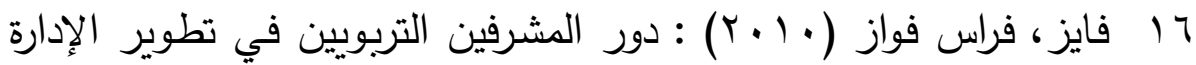
المدرسية كما يراها مديرو المدارس الحكومية في المحافظات الثمالية لوسط فلسطين ، رسالة ماجستير غير منشورة. ، كلية الدراسات العليا ، جامعة النجاح الوطنية في نابلس ، فلسطين IV مدارس وكالة الغوث الدولية في قطاع غزة ، رسالة ماجستير غير منشورة ، عمادة الدراسات العليا ، الجامعة الإسلامية بغزة .

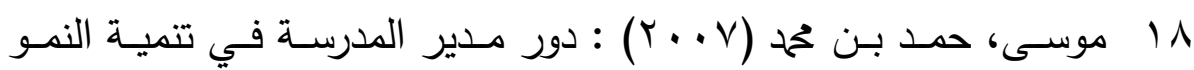
المهنى للمعلم بمحافظة القنفذة ( دراسة ميدانية ) ، رسالة ماجستير غير منشورة ، كلية التربية بمكة المكرمة ، جامعة أم القرى ، المملكة العربية

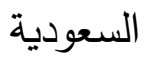

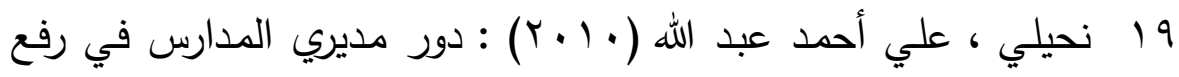
كفاية المعلمين ، مجلة جامعة دمشق ، المجلد (26) ، العدد الأول

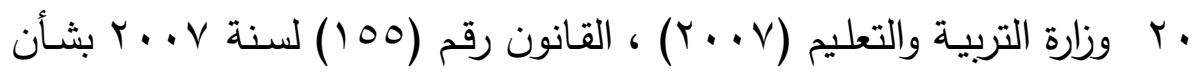
تعديل بعض أحكام قـانون التعليم الصـادر بالقـانون رقم (و ( ) لسـنة 
ا Y وزارة التربية والتعليم (^ . . Y) : وثيقة المعايير القومية لرياض الأطفال ،

مشـروع تحسين التعليم في مرحلـة الطفولـة المبكرة ، الطبعـة الأولىى ،

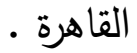

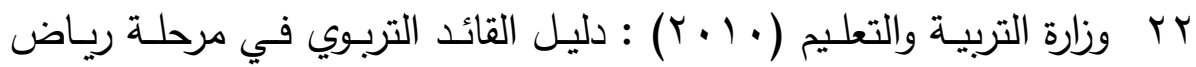
الأطفال ، مشروع تحسين التعليم في الطفولة المبكرة ، القاهرة

r r اليعقوبي ، علي بن راشد بن سالم (11) (1) : واقع فاعلية أداء تخطيط الموارد البشرية في ظل التخطيط الاستراتيجي في النظام التربوي بسلطنة عمـان ، رسـالة ماجستير غيـر منشـورة ، الأكاديميـة العربيـة البريطانيـة للتعليم العالي - مالي

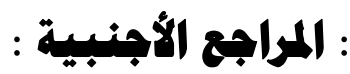

24 Barry, Z. Posner (2009). From Inside Out: Beyond Teaching about Leadership. Journal of Leadership Education. Volume (8). Issue (1)

25 Deborah, L. Saks (2009). Education at a Distance: Best Practices and Considerations for Leadership Educators. Journal of Leadership Education. Volume (8). Issue (1)

26 Edward, Sallis. (2002). Total Quality Management in Education. Third edition. London: Kogan Page Ltd

27 Geoff, Scott, Hamish Coates \& Michelle Anderson. (2008). Learning Leaders in Time of Change, Academic Leadership Capabilities for Australian Higher Education. University of 
Western Sydney and Australian Council for Educational Research. USA.

28 Gronuld, N.E (1981). Measurement and Evaluation in Teaching. Second Edition. New York. Macmillan

29 Jonas, Haertle. (2007). The Principles for Responsible Management Education. Third edition. UN Global Compact

30 Joseph, F. Albert and Kaitlin Vadla, B.S. (2009). Authentic Leadership Development in the Classroom "A Narrative Approach". Journal of Leadership Education. Volume (8). Issue (1)

31 Judy, D. Olian. (2002). Management Education at Risk. Management Education Task Force to the AACSB International Board of Director

32 Kelly, Rae Victor. (2005). Identifying Effective Behavior Management in the Early Childhood Classroom. Education Department. Cedarville University

33 Michelle, lapointe, Stephen Davis and Carol Cohen. (2007). Principal Preparation at Delta State University "A Bold Strategy to Improve Practice". Stanford Educational Leadership Institute, Stanford University. School of Education

34 Nathan, Harter. (2009). Critical Thinking in Groups. Journal 


\section{الملة العلمية لكلية رياض الأطفال ـ جامعة بورسعيد}

of Leadership Education. Volume (8), Issue (1)

35 Richard, A. Flanary and Joseph, H. Simpson. (2008). Educational Leadership Policy Standards “As Adopted by the National Policy Board for Educational Administration". Washington: The Council of Chief State School Officers

36 Ronald, H. Heck and Philip Hallinger. (2005). The Study of Educational Leadership and Management "Where Does the Field Stand Today”. Educational Management Administration \& Leadership. London: SAGE Publications. Vol. (33)

37 Steve, Strand. (2008). Key Performance Indicators for Primary School Improvement. British Educational Leadership. Management \& Administration Society. University of Warwick

38 Susan, R. Komives and Others. (2009). Leadership Identity Development "Challenges in Applying a Developmental Model". Journal of Leadership Education. Volume (8). Issue (1). 